\title{
Immunotherapy against endocrine malignancies: immune checkpoint inhibitors lead the way
}

\author{
Lucas Leite Cunha', Marjory Alana Marcello', Vinicius Rocha-Santos ${ }^{2}$ and \\ Laura Sterian Ward1 \\ 'Laboratory of Cancer Molecular Genetics, Faculty of Medical Sciences, University of Campinas (FCM-Unicamp), \\ Campinas, São Paulo, Brazil \\ 2Liver and Gastrointestinal Transplant Division, Department of Gastroenterology, University of São Paulo, School of \\ Medicine, São Paulo, São Paulo, Brazil
}

Correspondence should be addressed to L S Ward

Email

ward@fcm.unicamp.br

\begin{abstract}
Immune checkpoint inhibitors are agents that act by inhibiting the mechanisms of immune escape displayed by various cancers. The success of immune checkpoint inhibitors against several tumors has promoted a new treatment strategy in clinical oncology, and this has encouraged physicians to increase the number of patients who receive the immune checkpoint therapy. In the present article, we review the main concepts regarding immune checkpoint mechanisms and how cancer disrupts them to undergo immune escape. In addition, we describe the most essential concepts related to immune checkpoint inhibitors. We critically review the literature on preclinical and clinical studies of the immune checkpoint inhibitors as a treatment option for thyroid cancer, ovarian carcinoma, pancreatic adenocarcinoma, adrenocortical carcinoma and neuroendocrine tumors. We present the challenges and the opportunities of using immune checkpoint inhibitors against these endocrine malignancies, highlighting the breakthroughs and pitfalls that have recently emerged.
\end{abstract}

\author{
Key Words \\ - immune checkpoint \\ inhibitors \\ - endocrine neoplasms \\ - immune escape \\ - thyroid cancer \\ - ovarian cancer \\ - pancreatic adenocarcinoma \\ - neuroendocrine tumors \\ - adrenocortical carcinoma
}

Endocrine-Related Cancer (2017) 24, T261-T281

\section{Introduction}

Immune checkpoint inhibitors are agents that act by inhibiting immune escape through various mechanisms. In other words, immune checkpoint inhibitors act on the immune system (not necessarily on tumor cells), enabling it to detect, target and destroy cancer cells. By doing so, immune checkpoint inhibitors also activate immune memory, leading to a sustained antitumor response. Additionally, since these drugs primarily act on the host, it may be possible to use them against many tumor types, independent of the origin of cancer. The cost of enhancing the immune response is mirrored in adverse events, which are largely related to immune-mediated destruction of healthy tissues and uncontrolled inflammation.
Endocrine malignancies are a heterogeneous group of diseases that is composed of tumors with different biological features. Endocrine tumors are usually indolent, and their low proliferative capacity is one of their known signatures. On the other hand, very aggressive tumors such as anaplastic thyroid cancer and adrenocortical carcinomas are also included among endocrine neoplasms. Data derived from The Cancer Genome Atlas (https:// cancergenome.nih.gov/) demonstrated that these tumors present a low mutation burden, markedly lower than lung, bladder and upper gastrointestinal cancers (Agrawal et al. 2013, Bates 2016, Bongiovanni et al. 2017). Despite their low mutational load, many endocrine tumors

This paper forms part of a special section on Immunotherapy and Cancer. The guest editors for this section were Joanne Y Y Ngeow and Laura S Ward. Laura S Ward was not involved in the review process for this paper, on which they are listed as an ąuthor. $2: 02: 02 \mathrm{PM}$ 
harbor driver mutations that are commonly implicated in aggressiveness, making the endocrine neoplasms a very intriguing field for exploration.

In the present article, we review the main concepts regarding immune checkpoint mechanisms and how cancer disrupts them to undergo immune escape. We describe the most essential points related to the pharmacology and clinical aspects of immune checkpoint inhibitors. Finally, we critically review the literature on preclinical and clinical studies of immune checkpoint inhibitors as a treatment option for some endocrine malignancies.

\section{Concepts in immune checkpoints and immune checkpoint inhibitors}

The immune system avoids autoimmunity by turning off immune responses against cells of the host organism. This means that there are several mechanisms responsible for the inactivation of effector $\mathrm{T}$ cells that prevent damage to healthy tissues despite the continuing clearance of

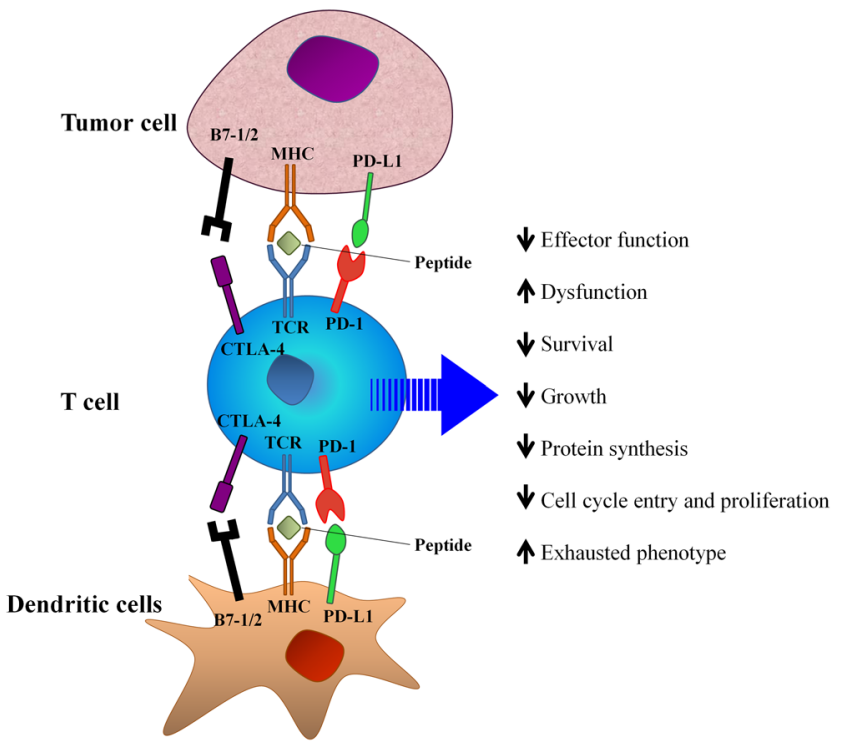

\section{Figure 1}

Immunological synapse, showing tight contact between a T cell and an antigen-presenting cell. In the lower part of the image, the T-cell interacts with a dendritic cell, and the peptide is presented by $\mathrm{MHC}$ and recognized by TCR. In the upper part of the image, the tumor cell performs an analogous presentation of the tumor-associated antigen. When antigen presentation occurs in the context of inhibitory molecules (CTLA-4/B7-1/2 or PD-1/PD-L1), a negative signal is triggered in the cytoplasm of the T-cell. This negative signal leads to the downregulation of effector functions, inhibition of survival, growth and proliferation and stimulation of an exhausted phenotype in T cells. Cancer cells disrupt immune responses by hijacking this mechanism, thereby avoiding tumor destruction and elimination. infectious microorganisms. Cancer takes advantage of this property of the immune system to avoid its own elimination by immune cells by using a process called immune escape (Ramsay 2013). One mechanism of immune escape is the hijacking of immune cell-intrinsic checkpoints that are induced by T-cell activation (Fig. 1) (Pardoll 2012, Ribas 2012).

\section{Cytotoxic T-lymphocyte-associated antigen 4 (CTLA-4) and anti-CTLA-4 antibody}

T-cell recognition of antigen through the T-cell receptor (TCR) is regulated by a balance between costimulatory and inhibitory signals T-cell recognition of antigen through the TCR is regulated by a balance between costimulatory and inhibitory signals.

One of the immune checkpoints is mediated by CTLA-4. CTLA-4 is active in the initial stages of the immune response, is expressed by $\mathrm{T}$ cells after $48 \mathrm{~h}$ of activation and participates in dominant negative signaling by competing with the CD28 costimulatory receptor for the binding of B7-1 (CD80) and B7-2 (CD86) (Ribas 2012). CTLA-4-deficient mice develop a phenotype characterized by immune hyperactivation and lymphoproliferative disease with multiorgan lymphocytic infiltration and tissue destruction (Tivol et al. 1995). Similarly, the in vivo blockage of CTLA-4 in animal models augments immune responses, resulting in the rejection of tumors, including pre-established tumors. Interestingly, this also results in immunity against secondary exposure to tumor cells, suggesting that the memory component of immune response can be evoked by anti-CTLA- 4 antibodies (Leach et al. 1996).

Ipilimumab Ipilimumab is a recombinant fully humanized monoclonal IgG class 1 antibody that is directed against CTLA-4 (Fig. 2). This antibody is currently approved by the FDA for the treatment of metastatic melanoma and as an adjuvant therapy for patients with stage III melanoma (Hodi et al. 2010, Eggermont et al. 2016). Ipilimumab binds to CTLA-4 expressed on T cells and inhibits the CTLA-4-mediated downregulation of T-cell activation, leading to a cytotoxic T-cell-mediated immune response against cancer cells. The detailed mechanisms of action of CTLA-4 blockade with ipilimumab are not fully understood, but it is estimated that they can be classified into two main types: cell-intrinsic mechanisms acting in cis and cell-extrinsic mechanisms acting in trans (de Coana et al. 2017). The cis mechanisms involve

Published by Bioscientifica Ltc.
(C) 2017 Society for Endocrinology Printed in Great Britain 


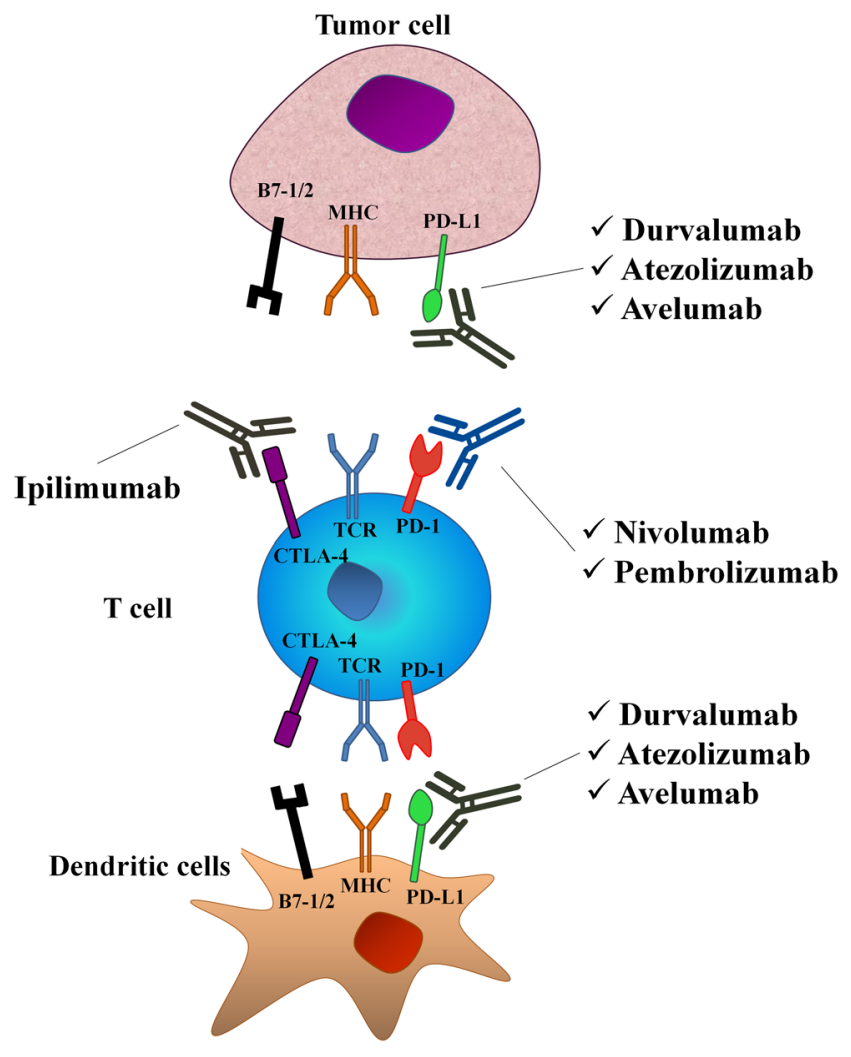

Figure 2

Immunological synapse after the administration of immune checkpoint inhibitors. Immune checkpoint inhibitors are antibodies directed against co-inhibitory molecules. By blocking the interaction between CTLA-4 and B7-1/2 (e.g., ipilimumab) or PD-1 (e.g., nivolumab and pembrolizumab) and PD-L1 (e.g., durvalumab, atezolizumab and avelumab), immune checkpoint inhibitors inhibit the immune response mediated by immune escape mechanisms and encourage the immune system to destroy tumor cells.

T cells that express CTLA-4, which remain suppressed (Leach et al. 1996). In this case, the blockage of CTLA-4 activates the cells, allowing them to proliferate and perform their functions. The trans mechanisms involve other cell types, including regulatory $\mathrm{T}$ cells and myeloidderived suppressive cells (Walker \& Sansom 2011). In this case, the anti-CTLA- 4 treatment reduces the suppressive potential of these cells (Pico de Coana et al. 2013). In both cis and trans mechanisms, ipilimumab acts to favor the breakdown of the tumor immune escape, leading to an antitumor immune response.

The pharmacokinetics of ipilimumab were investigated in 499 patients with unresectable or metastatic melanoma. Studies were performed by administering ipilimumab every 3 weeks, in 4 cycles. Patients received the drug at three doses, namely, $0.3,3$ or $10 \mathrm{mg} / \mathrm{kg}$, and the third dose allowed a steady-state concentration. Within the dose range examined, the plasma peak, trough and area under the curve concentrations of ipilimumab were proportional to the dose (Wolchok et al. 2010, Fellner 2012). The maximum CTLA- 4 blockade occurred at the concentration of $20 \mu \mathrm{g} / \mathrm{mL}$, and $30 \%$ of patients in the group receiving $3 \mathrm{mg} / \mathrm{kg}$ experienced this effect (Wolchok et al. 2010). No dosage adjustment was indicated for high body weight, preexisting mild-to-moderate renal insufficiency (creatinine clearance of $29 \mathrm{~mL} / \mathrm{min}$ or above) or various degrees of hepatic dysfunction at baseline because these factors did not show a meaningful effect on the pharmacokinetics of ipilimumab. Other factors that did not appear to significantly impact the clearance of ipilimumab include age, gender, concomitant use of budesonide, performance score, HLA-A2*0201 status, antiipilimumab antibody positivity, prior history of systemic anticancer therapy and baseline lactate dehydrogenase levels (Wolchok et al. 2010, Trinh \& Hagen 2013).

\section{Programmed cell death protein 1 (PD-1) and programmed cell death protein ligand (PD-L1) axis and PD-1/PD-L1 blockade}

The PD-1/PD-L1 axis is involved in multiple stages of the immune response. The activation of $\mathrm{T}$ cells triggers the expression of PD-1, which is maintained after T cells migrate to peripheral tissues. The cytokines produced in peripheral tissues provide a microenvironment that induces the expression of PD-L1 and PD-L2. The signals through the PD-1/PD-L1 axis are inhibitory in nature, resulting in decreases in the expression of cell surface activation markers, the proliferation of $\mathrm{T}$ cells and the production of cytokines (Butte et al. 2007). This produces a precise regulation of the T-cell response, preventing uncontrolled inflammation and autoimmunity (Keir et al. 2006, 2008).

Notably, both the PD-1/PD-L1 axis and regulatory $\mathrm{T}$ cells are necessary for the maintenance of peripheral tolerance. Francisco and coworkers derived both of these concepts while studying regulatory T-cell plasticity (Francisco et al. 2009). The authors demonstrated that the expression of PD-L1 by antigen-presenting cells is essential for the induction of differentiation of regulatory $\mathrm{T}$ cells from naïve CD4 T cells. Additionally, PD-L1 enhances and sustains FOXP3 expression and the suppressive function of induced Treg cells (Francisco et al. 2009). PD-1 is also expressed by B cells and natural killer-cell effectors; PD-L1 is expressed by $\mathrm{B}$ cells, $\mathrm{T}$ cells and macrophages, whereas PD-L2 is mainly expressed by antigen-presenting cells and epithelial cells (Keir et al. 2008, Gravelle et al. 2017).

Published by Bioscientifica Ltd. 
The molecule PD-1 interacts with PD-L1 and PD-L2. The relative contribution of PD-L2 is not completely understood. PD-L2 is expressed later in the maturation of dendritic cells and at lower levels. Shin and coworkers have shown that PD-L2, but not PD-L1, elicits direct activating effects on dendritic cells (Shin et al. 2005). However, the concurrent presence of PD-L1 on the same cell might prevent this activating effect of PD-L2 due to competition for PD-1. Indeed, Ghiotto and coworkers observed that PD-L1 and PD-L2 competed for PD-1 binding and that conversely, an antagonist PD-1 monoclonal antibody blocked both PD-L1 and PD-L2 from binding to PD-1 and strongly enhanced T-cell proliferation (Ghiotto et al. 2010).

Many chronic infections are characterized by the functional impairment of antigen-specific $\mathrm{T}$ cells by a process called T-cell exhaustion, and it has been demonstrated that PD-1 is involved in this process. Barber and coworkers reported that PD-1 was selectively upregulated by exhausted $\mathrm{T}$ cells in mice chronically infected with lymphocytic choriomeningitis virus (Barber et al. 2006). Blocking the interaction of PD-1 with PD-L1 restored the ability of the T cells to undergo proliferation, secrete cytokines, kill infected cells and decrease viral load, suggesting that the PD-1/PD-L1 axis is a key mechanism for anergy (Barber et al. 2006). This mechanism might also contribute to the immune response against tumors. Notably, hematological malignancies and solid tumors are frequently enriched with tumor-infiltrating lymphocytes in which PD-1 is markedly upregulated, whereas the ligands PD-L1 and PD-L2 are expressed by various types of tumor cells, reinforcing the hypothesis that the PD-1/ PD-L1 axis is a mechanism co-opted by tumors in order to evade the immune system (Ahmadzadeh et al. 2009, Cunha et al. 2013b, Wu et al. 2015, Gravelle et al. 2017).

Nivolumab Nivolumab is a fully humanized $\operatorname{IgG}$ class 4 antibody that binds to PD- 1 with high affinity, preventing its interaction with both PD-L1 and PD-L (Fig. 2). The blockage of these interactions results in the loss of inhibitory signals in $\mathrm{T}$ cells and tumor recognition by cytotoxic $\mathrm{T}$ cells, stimulating the memory response to tumor antigen-specific T-cell proliferation (Wang et al. 2014, Guo et al. 2017). This antibody is currently approved by the FDA for the treatment of metastatic melanoma, advanced non-small-cell lung cancer, advanced renal cell carcinoma, recurrent or metastatic squamous cell carcinoma of the head and neck after previous treatment, recurrent classical Hodgkin lymphoma after an autologous stem cell transplantation and previously treated advanced bladder cancer. The peak concentration of nivolumab is achieved by $1-4 \mathrm{~h}$ after the start of infusion, and its serum halflife is $12(0.3,1.0$ or $3.0 \mathrm{mg} / \mathrm{kg})$ to 20 days $(10.0 \mathrm{mg} / \mathrm{kg})$ (Brahmer et al. 2015). The binding of nivolumab with PD-1 was analyzed by PD-1 occupancy, which was found to be dose independent, with a mean peak occupancy of $85 \%$ at $4-24 \mathrm{~h}$ and an average plateau occupancy of $72 \%$ at 57 days and beyond (Brahmer et al. 2010). Bajaj and coworkers demonstrated that sex, performance status, baseline estimated glomerular filtration rate, age, race, baseline lactate dehydrogenase, mild hepatic impairment, tumor type, tumor burden and PD-L1 expression had significant but not clinically relevant $(<20 \%)$ effects on nivolumab clearance (Bajaj et al. 2017).

Pembrolizumab Pembrolizumab is a humanized recombinant monoclonal IgG class 4 kappa-isotype antibody to PD-1, and it results in an increased immune reactivity that can overcome immune tolerance, thus enabling its use in immunotherapy (Fig. 2) (Raedler 2015). Pembrolizumab is indicated for the treatment of unresectable or metastatic melanoma, metastatic non-small-cell lung cancer with high PD-L1 expression and recurrent or metastatic head and neck squamous cell carcinoma with disease progression on or after platinum-containing chemotherapy, and it has recently been approved by the FDA for use in adult and pediatric patients with refractory classical Hodgkin lymphoma or patients who have relapsed after three or more prior lines of therapy. Pharmacokinetic studies have revealed that the steady-state concentration of pembrolizumab was reached by 19 weeks of repeated dosing with administration every 3 weeks, and the systemic accumulation was 2.2 -fold. Age, sex, ethnicity, renal impairment, mild hepatic impairment and tumor burden had no clinically important effect on the clearance of pembrolizumab (Merck 2017). Phase I, II and III clinical trials have assessed different pembrolizumab regimens administered every 2 or 3 weeks (Garon et al. 2015, Ribas et al. 2015, Robert et al. 2015). These studies helped to establish that the approved pembrolizumab dose of $2 \mathrm{mg} / \mathrm{kg}$ every 3 weeks without dose adjustment in a variety of patient subpopulations is probably the best regimen available at present. (Ahamadi et al. 2017). The authors found no clinical significance for variations in sex, baseline performance status, renal and hepatic function, 
tumor type and burden or prior ipilimumab treatment on pembrolizumab exposure (Ahamadi et al. 2017).

Durvalumab Durvalumab is an Fc-optimized monoclonal antibody directed against PD-L1 with potential immune checkpoint inhibitory and antineoplastic activities (Fig. 2). On May 1, 2017, the U.S. FDA granted accelerated approval to durvalumab for the treatment of patients with locally advanced or metastatic urothelial carcinoma who have disease progression during or following platinum-containing chemotherapy or within 12 months of neoadjuvant or adjuvant treatment with platinum-containing chemotherapy. By binding to PD-L1, durvalumab can reverse T-cell inactivation and encourage the immune system to exert a cytotoxic T-lymphocytemediated response against PD-L1-expressing tumor cells. Steady-state concentration of durvalumab was achieved at approximately 16 weeks (AstraZeneca 2017). The steadystate clearance of durvalumab was $8.24 \mathrm{~mL} / \mathrm{h}$, and the geometric mean terminal half-life was approximately 17 days. The pharmacokinetics of durvalumab were not clinically significantly affected by age, body weight, sex, albumin levels, lactate dehydrogenase levels, creatinine levels, soluble PD-L1, tumor type, race, mild renal impairment, moderate renal impairment, mild hepatic impairment or Eastern Cooperative Oncology Group (ECOG) status (AstraZeneca 2017).

Atezolizumab Atezolizumab is an Fc-engineered, fully humanized monoclonal antibody of an IgG1 isotype against PD-L1 (Fig. 2). Atezolizumab is FDA approved for locally advanced or metastatic urothelial carcinoma and metastatic non-small-cell lung cancer during or following platinum-containing chemotherapy (Ning et al. 2017). Similar to durvalumab, atezolizumab binds to PD-L1 and inhibits its interaction with PD-1. This releases the PD-1/ PD-L1-mediated inhibition of the immune response, resulting in the reactivation of the antitumor immune response (Ning et al. 2017). Based on a population analysis that included 472 patients given various doses, the typical population clearance of atezolizumab was $0.20 \mathrm{~L} /$ day, the volume of distribution at steady state was $6.9 \mathrm{~L}$ and the terminal half-life was 27 days. The population pharmacokinetics analysis suggests that the steady state is obtained after 6-9 weeks (2-3 cycles) of repeated dosing. Atezolizumab clearance was found to decrease over time, with a mean maximal reduction from baseline value of approximately $17.1 \%$. The systemic exposure of atezolizumab was not clinically significantly affected by age, body weight, gender, positive anti-therapeutic antibody status, albumin levels, tumor burden, region or race, mild or moderate renal impairment, mild hepatic impairment, level of PD-L1 expression or ECOG status (Genentech 2017, Ning et al. 2017).

Avelumab Avelumab is an investigational fully humanized anti-PD-L1 IgG1 monoclonal antibody. In 2017, the U.S. FDA granted accelerated approval to avelumab for the treatment of patients aged 12 years and older with metastatic Merkel cell carcinoma (Kim 2017). Avelumab is also included in the international JAVELIN clinical trial, as both monotherapy and combination therapy in more than 16 different tumor types (Chin et al. 2017). Avelumab binds PD-L1 and blocks the interaction between PD-1 and PD-L1 (Fig. 2). By inhibiting PD-L1 interactions, avelumab is thought to enable the activation of $T$ cells and the adaptive immune response. By retaining a native Fc region, avelumab is thought to engage the innate immune response and induce antibody-dependent cell-mediated cytotoxicity, prompting the restoration of antitumor immune responses (Disis et al. 2016, Chin et al. 2017, Kim 2017). The steady-state concentration of avelumab was achieved after approximately 4-6 weeks (2-3 cycles) of repeated dosing. In patients with solid tumors, the total systemic clearance was $0.59 \mathrm{~L} /$ day, and the terminal half-life was 6.1 days in patients receiving $10 \mathrm{mg} / \mathrm{kg}$ (Serono 2017).

\section{New immune checkpoint inhibitors}

Inspired by the success of checkpoint inhibitors, several other checkpoints are now under investigation as targets for monotherapy or as combination therapy, including lymphocyte activation gene-3 (LAG-3), T-cell immunoglobulin mucin-3 (TIM-3) and indoleamine-2,3dioxygenase (IDO) (Brignone et al. 2010, Wang-Gillam et al. 2013, Beatty et al. 2017).

LAG-3 Also called CD223, LAG-3 is expressed on activated T cells, NK cells, B cells and tumor-infiltrating lymphocytes (Grosso et al. 2007, Assal et al. 2015). LAG-3 acts as a negative regulator of T-cell activation and homeostasis (Grosso et al. 2007). LAG-3 exhibits its effects on immunity through several mechanisms: induction of functional unresponsiveness of T cells, inhibition of TCRinduced calcium ion flux, inhibition of cytokines and promotion of the suppressive activity of Treg cells (Huang et al. 2004). LAG-3 and PD-1 are co-expressed in malignant

Published by Bioscientifica Ltd. 
mouse and human tissues, and in these malignant microenvironments, it leads to immune tolerance by inhibiting APC and T-cell function (Woo et al. 2012, Lee et al. 2013). Similar to anti-PD-1 immunotherapy, anti-LAG-3 has been shown to reduce tumor growth of colorectal adenocarcinoma and fibrosarcoma in mice, and it produces a synergistic effect when co-administered with anti-PD-1 (Woo et al. 2012). In the last few years, studies have investigated the use of IMP321, a LAG-3-Ig recombinant fusion protein that antagonizes the normal function of LAG-3. These studies were focused on renal cell carcinoma (Brignone et al. 2009), metastatic breast carcinoma (Brignone et al. 2010) and advanced pancreatic adenocarcinoma (Wang-Gillam et al. 2013). All these studies showed promising results regarding the effect of LAG-3 in reducing tumor size. In addition, these studies demonstrated that LAG-3 is well tolerated by patients, making it a suitable candidate for immunotherapy.

TIM-3 T-cell immunoglobulin mucin-3 was first identified as a molecule specifically expressed on IFN- $\gamma$ secreting CD4 T helper 1 and CD8 cytotoxic T cells in both mice and humans (Zhu et al. 2011). TIM-3 acts as a negative regulatory molecule by binding with one of its ligands, Galectin-9 (Gal-9). When this binding occurs, Gal-9 leads to cell death, especially in $\mathrm{T}$ cells whose activities have been suspended. TIM-3 can also impair immune responses by promoting the expansion of myeloid-derived suppressor cells (Sakuishi et al. 2011). Tumor-infiltrating CD4 and CD8 cells co-express TIM-3 and PD-1 in murine models of colon adenocarcinoma, melanoma and mammary adenocarcinoma (Assal et al. 2015). In humans, TIM-3 is expressed on tumorinfiltrating lymphocytes or $\mathrm{T}$ cells in the peripheral blood of patients with various types of cancer such as hepatocellular cancer, cervical cancer, colorectal cancer, ovarian cancer, non-small-cell lung cancer, head and neck cancer, renal cell carcinoma, gastric cancer, esophageal cancer, prostate cancer and non-Hodgkin lymphoma (Yang et al. 2012, Jie et al. 2013, Yan et al. 2013, Cheng et al. 2015, Japp et al. 2015, Ji et al. 2015, Thommen et al. 2015, Cai et al. 2016, Xie et al. 2016). Preclinical models show conflicting results for the administration of TIM3-targeting monoclonal antibody. While administration of the antibody alone did not show promising results in colon adenocarcinoma, the combination of anti-TIM-3 and anti-PD-1 antibodies demonstrated a considerable antitumor effect (Sakuishi et al. 2010). The same occurred with the co-administration of anti-TIM-3 and anti-CTLA-4 antibodies in a mouse model (Ngiow et al. 2011). Taken together, these studies suggest that the combination of anti-TIM-3 with anti-PD-1 or anti-CTLA-4 shows promise for the improvement of current immunotherapy.

IDO Indoleamine 2,3-dioxygenase (IDO) is an IFNinducible enzyme that suppresses adaptive T-cell immunity by catabolizing the essential amino acid tryptophan from the cellular microenvironment (Mellor 2005, Wingender et al. 2006). When tryptophan levels are decreased, the cell cycle is arrested with the inactivation of mTOR pathway, and tryptophan metabolites lead to T-cell apoptosis and Treg cell differentiation (Assal et al. 2015). One of the IDOs, IDO1, is expressed in mature dendritic cells in lymphoid tissues, some epithelial cells of the female genital tract and placental and pulmonary endothelial cells, and IDOs can also be found in lymphoid tissues of tumors such as cervical, colorectal, gastric tumors, as well as vascular cells in renal cell cancer (Theate et al. 2015). Tumors expressing IDO1 have a more aggressive phenotype and lead to poorer prognosis than tumors that do not express this protein (Godin-Ethier et al. 2011). There are several ongoing studies investigating the effect of the IDO inhibitor indoximod both alone and in combination with other antitumoral agents (Assal et al. 2015, Jiang et al. 2017, Meng et al. 2017, Tomek et al. 2017).

\section{Combination of therapies}

Radiotherapy utilizes the DNA-damaging properties of ionizing radiation to kill tumor cells, promoting the control of tumor growth. Preclinical investigations demonstrated that radiotherapy can induce an immunogenic cell death and promote the activation of the T-cell response, establishing a proimmunogenic milieu (Golden et al. 2014). Immunogenic cell death is defined as the cell death that occurs associated with an improvement of molecular signals that culminate in maturation of antigen-presenting cells. Once antigen-presenting cells are mature, they can cross-present tumor antigens to $\mathrm{T}$ cells, leading to an effective immune response (Tesniere et al. 2008, Pilones et al. 2015). By removing the obstacles hindering the activation and function of antitumor immune cells, inhibitors of immune checkpoints would benefit patients with antitumor immunity activated by radiotherapy (Pilones et al. 2015).

Lenvatinib is an oral, multi-targeted tyrosine kinase inhibitor that impairs several signaling networks implicated in tumor growth and maintenance. This drug
(C) 2017 Society for Endocrinology Printed in Great Britain
Published by Bioscientifica Ltd. 
is indicated for treatment of locally recurrent or metastatic progressive, radioiodine-refractory differentiated thyroid cancer (Frampton 2016). The rationale for the use of lenvatinib plus pembrolizumab is not fully understood. However, it seems reasonable that actions occurring via different mechanisms may synergize to produce the antitumor activity. In particular, preliminary results in patients with selected solid tumors demonstrated that the combination of lenvatinib and pembrolizumab has antitumor activity with partial responses, manageable toxicities and no new safety signals identified (Taylor et al. 2016).

Lenvatinib, as an angiogenic inhibitor targeting vascular endothelial growth factor receptor (VEGFR) and fibroblast growth factor receptor (FGFR), may synergically act with immune checkpoint inhibitors (Tartour et al. 2011, Kuusk et al. 2017). This rationale is supported by the observation that proinflammatory cytokines indirectly induce angiogenesis mediated by VEGF expression (Neufeld \& Kessler 2006). Reciprocally, antiangiogenic agents have an effect by decreasing myeloid-derived suppressor cell (Ko et al. 2009), regulatory T cells (Finke et al. 2008), immunosuppressive cytokines in the tumor microenvironment (Ozao-Choy et al. 2009) and the expression of negative costimulatory molecules CTLA4 and PD-1 in both CD4+ and CD8+ cells (Ozao-Choy et al . 2009). In addition, antiangiogenic agents may increase tumor-specific CD8+ cells, favoring tumor regression (Manning et al. 2007).

\section{The prediction of response to immune checkpoint inhibitors}

The success of the immune checkpoint inhibitors against several types of tumors has promoted a new treatment strategy in clinical oncology, and this has encouraged physicians to increase the number of patients who receive the immune checkpoint therapy. However, the cost of these drugs and their adverse effects indicate that a predictor of clinical response is urgently needed.

Oneattemptatpredictioninvolvesthehistopathological assessment of the tumor microenvironment, which could hypothetically identify the tumors that would be more or less vulnerable to checkpoint blockage (Taube et al. 2012, Teng et al. 2015). According to this proposal, the tumor microenvironment could be classified into four distinct categories: type I, PD-L1-positive and presence of tumor-infiltrating lymphocytes; type II, PD-L1-negative and absence of tumor-infiltrating lymphocytes; type III,
PD-L1-positive and absence of tumor-infiltrating lymphocytes and type IV, PD-L1-negative and presence of tumor-infiltrating lymphocytes. Type I reflects a tumor microenvironment in which the gamma interferon released by tumor-infiltrating lymphocytes probably mediates the upregulation of PD-L1 in tumor cells. Thus, the type I tumors are most likely to benefit from singleagent anti-PD-1/L1 blockade, since this therapy would restore the activation of tumor-infiltrating lymphocytes by shutting down the immune escape mechanism (Teng et al. 2015). By contrast, the type II tumor microenvironment completely lacks cellular immune responses, and a poorer prognosis is thought to be associated with these tumors. At this point, it is worthwhile to note that CTLA4 blockade frequently induces increases in the intratumoral infiltration of CD8+ cells in biopsy samples (Huang et al. 2011). Hence, one could believe that the combination of anti-CTLA-4 and anti-PD-1 therapy would benefit patients with type II tumor microenvironment (Teng et al. 2015). The type III microenvironment is probably a consequence of constitutive PD-L1 expression due to oncogenic signaling (Azuma et al. 2008, Teng et al. 2015). The type IV microenvironment is likely associated with extrinsic mechanisms of immune escape, such as infiltration of myeloid-derived suppressor cells, regulatory $\mathrm{T}$ cells and M2 macrophages (Teng et al. 2015).

This model has some limitations. Most observations used in this model were made and validated in patients with melanoma, and few studies could replicate the same model in patients with non-melanoma solid tumors and hematological malignancies (Taube et al. 2014, Velcheti et al. 2014, D'Incecco et al. 2015). Even if the classification of the microenvironment can be obtained by simple laboratory methods, it is plausible that a mere slice of the tumor cannot fully reflect the complexity inherent in the biology of the immune-tumor interaction. Furthermore, adding to this complexity, we must consider the tumor heterogeneity and focal expression of PD-L1. Thus, a negative immunohistochemical result may not be representative of the expression of all malignant cells presented in tumor microenvironment (Taube et al. 2014). In addition, even when PD-L1 is expressed, the definition of true positivity is not completely safe from subjectivity (Taube et al. 2014, Teng et al. 2015).

Although PD-L1 expression in tumor cells correlates with the response to PD-1/PD-L1 blockage therapy (Taube et al. 2014, Daud et al. 2016), the clinical benefit is not limited to patients whose tumors are positive for PD-L1 (Herbst et al. 2014), suggesting that the expression of PD-L1 
in tumor cells cannot be fully translated to the clinic as an isolated criterion (biomarker) for the indication of PD-1/ PD-L1 blockage. It is possible that other characteristics of the immune microenvironment may also be important in predicting the effect of PD-L1 blockage. Tumors that respond to anti-PD-L1 therapy present elevated expression of IFN as well as of IFN-inducible genes (Herbst et al. 2014). In addition, the activation of PD-1/PD-L1 axis is a dynamic process and PD-L1 blockage may subject tumors to changes in their immune microenvironment. Patients treated with anti-PD-L1 antibody experienced a decrease in tumor size, accompanied by an increase in PD-L1 expression on tumor-infiltrating immune cells and tumor cells (Herbst et al. 2014). Additionally, unidentified factors may contribute to the response observed in patients whose tumors are negative for PD-L1. These considerations may help explain why patients whose tumors show weak or absent PD-L1 staining may still benefit from PD-1/PD-L1 blockage.

\section{Challenges and opportunities for immune checkpoint inhibitors in ovarian cancer}

Ovarian cancer is the most lethal gynecologic malignancy, and it is also considered an endocrine neoplasm. In the USA, 22,400 new cases of ovarian cancer are expected during 2017, resulting in 14,800 estimated deaths in the same year (Siegel et al. 2017). The mortality can be partially explained by advanced tumor stages at diagnosis. In particular, $60 \%$ of patients are diagnosed with distant metastasis, $20 \%$ with tumors spread to regional lymph nodes and a minority $(14.8 \%)$ with disease confined to the primary site (with the remaining patients being of unknown stage) (Surveillance, Epidemiology, and End Results (SEER) database; https:// seer.cancer.gov/). A great majority (95\%) of ovarian cancers are derived from epithelial cells and other ovarian cell types, which include germ cell tumors and sex cord-stromal tumors (Berek et al. 2015). High-grade serous carcinoma is the most common ovarian neoplasm, typically bearing TP53 and BRCA mutations and accounting for the majority of deaths (Kurman 2013). More than 60\% of patients with epithelial ovarian cancer will relapse after platinumbased initial therapy, especially those patients diagnosed with stage III or IV disease (Jayson et al. 2014). They will eventually stop responding to systemic treatment, contributing to the very high mortality rates for this cancer. These statistics have prompted the physicians to investigate immune responses in ovarian cancer, seeking the development of new immunotherapeutic approaches.
Melichar and coworkers noted the presence of costimulatory molecules (CD80 and CD86) in lymphocytes in the ascitic fluid from patients with ovarian carcinoma and other types of peritoneal carcinomatosis (Melichar et al. 2000). Although CD28 (receptor for CD80 and CD86) was detected in the majority of CD3 cells, CTLA-4 expression on intraperitoneal tumor-infiltrating lymphocytes or peripheral blood mononuclear cells was infrequent, suggesting that this immune checkpoint is not a key mechanism by which lymphocytes promote tumor escape for ovarian tumors with peritoneal dissemination. In contrast, CTLA-4, in addition to PD-1, seems to be an important mechanism of suppression of antitumor immune response by myeloid-derived suppressor cells. Indeed, the blockage of PD-1, CTLA-4 or both in myeloid-derived suppressor cells could significantly reduce arginase I activity, a potent mechanism of local immune suppression, supporting the notion that CTLA-4 is important for immune escape led by myeloid-derived suppressor cells (Liu et al. 2009).

One in vivo study with a syngeneic murine ovarian cancer model demonstrated that the efficacy of CTLA- 4 blockage was potentiated by combined treatment with decitabine, a DNA methyl transferase inhibitor (Wang et al. 2015). Additionally, improvement in survival was achieved by treating an immunocompetent model of BRCA1-deficient murine ovarian cancer with CTLA-4 blockage combined with targeted cytotoxic therapy using a PARP inhibitor (Higuchi et al. 2015). The same experiments demonstrated that the favorable outcome was mediated by an increase in the proportion of cytotoxic cells with an effector/memory phenotype (Higuchi et al. 2015). This leads to the question of how we can translate the blockage of CTLA-4 for human patients with ovarian cancer.

Table 1 summarizes the results obtained from clinical trials testing immune checkpoint inhibitors in patients with ovarian cancer. The first attempt to use ipilimumab in patients with ovarian cancer was reported by Hodi and coworkers (Hodi et al. 2003). They infused ipilimumab into two female patients with metastatic ovarian cancer who were previously vaccinated with irradiated, autologous granulocyte-macrophage colony-stimulating factorsecreting tumor cells. The authors observed a reduction or stabilization of CA-125 levels in the two patients. The authors proceeded with the investigation and treated another nine stage IV ovarian carcinoma patients by using the same antibody after the same vaccination protocol (Hodi et al. 2008), but significant antitumor effects were 
observed only in a minority of patients. The authors demonstrated that the safety profile of the treatment was positive, and only two patients experienced grade 3 adverse effects with gastrointestinal toxicities. One of the patients achieved a dramatic reduction in CA-125 levels several months after the initial dose of ipilimumab, along with a substantial regression of a large, cystic hepatic metastasis and the complete resolution of mesenteric lymphadenopathy and thickening of the gastrocolic ligament. Three additional patients achieved stable disease for at least 2 months.

A phase II, open-label clinical trial (NLM 2017) investigated ipilimumab as monotherapy for the treatment of women with platinum-sensitive ovarian cancer and recurrent disease. Forty patients were intravenously injected with $10 \mathrm{mg} / \mathrm{kg}$ of ipilimumab once every 3 weeks for a total of 4 doses (induction phase), followed by additional doses once every 12 weeks (maintenance phase) until disease progression or unacceptable toxicity occurred. The primary outcome measure was the number of participants with drug-related adverse events of grade 3 (severe) or higher. The secondary outcome measure was the best overall response rate, defined as the proportion of patients who received treatment and, during the study, experienced complete or partial response confirmed by RECIST or CA-125 levels. The median age of the patients in the study was 61.5 , ranging from 42 to 74 years. Two patients completed the induction phase, and 38 did not (17 due to drug toxicity, 14 due to disease progression, 1 due to adverse events not related to the drug, 1 due to death and 5 not reported). Of the 2 patients admitted to the maintenance phase, 1 experienced drug toxicity, and the other decided to withdraw. The best overall response rate was observed in $10.3 \%$ of patients according to RECIST and in $11.1 \%$ according to CA-125 levels. Twenty-six patients (65\%) presented with serious adverse events, such as pneumonitis (10\%), diarrhea (10\%), small intestinal obstruction (10\%), adrenal insufficiency (7.5\%), hyponatremia, colitis, pleural effusion and incisional hernia ( $5 \%$ for each event). Among all adverse events, diarrhea $(65 \%)$, fatigue $(52.5 \%)$, pruritus $(52.5 \%)$, rash $(42.5 \%)$ and nausea $(42.5 \%)$ were the most frequent. Notably, the dose used by the authors $(10 \mathrm{mg} / \mathrm{kg})$ was higher than that approved by the FDA for metastatic melanoma $(3 \mathrm{mg} / \mathrm{kg})$ but similar to the phase III clinical trial that investigated ipilimumab as an adjuvant therapy after complete resection of high-risk stage III melanoma (Eggermont et al. 2015). Comparing both studies that used $10 \mathrm{mg} / \mathrm{kg}$ of ipilimumab, adverse events leading to discontinuation occurred in $17 / 40(42.5 \%)$ of patients with ovarian cancer, while the same outcomes were observed in $245 / 471$ (52\%) of patients with stage III melanoma. Larger clinical trials using ipilimumab for ovarian cancer are still ongoing.

Another important immune checkpoint mechanism in ovarian cancer is mediated by the PD-1/PD-L1 axis. Abiko and coworkers by studying ovarian cancer cell lines, observed that tumor cell lysis by cytotoxic $T$ cells was attenuated when PD-L1 was overexpressed, whereas it was promoted when PD-L1 was silenced (Abiko et al. 2013). They demonstrated that PD-L1 overexpression inhibited aggregation and degranulation of cytotoxic $\mathrm{T}$ cells, suggesting that PD-1/PD-L1 activation may also promote the exhaustion and dysfunction of cytotoxic T cells. On the other hand, PD-L1 on tumor cells may be induced by IFN- $\gamma$ from cytotoxic $T$ cells, and it may expel cytotoxic $\mathrm{T}$ cells from the tumor epithelium to the stroma, especially in ovarian cancer with peritoneal dissemination (Abiko et al. 2015). This supports the idea that complex crosstalk between tumor-infiltrating lymphocytes and ovarian tumor cells may mediate the PD-1/PD-L1 axis activation. It is not surprising that patients with ovarian cancer who were stratified based on high levels of tumor-infiltrating lymphocytes (tumors enriched with CD4+, CD8+ and PD-1+ cells) and low expression of immune regulatory molecules (TGFB1, PD-L1, PD-L2, COX-1 and COX-2) had significantly better prognosis than patients in the other groups (Hamanishi et al. 2011). Taken together, the preclinical results led scientists to pursue the blockage of the PD-1/PD-L1 axis as a therapy for patients with ovarian cancer.

In a single-center, open-label, phase II trial, Hamanishi and coworkers published interesting results (Hamanishi et al. 2015). They enrolled 20 patients with platinumresistant recurrent or advanced ovarian cancer to receive intravenous infusion of nivolumab every two weeks at a dose of $1 \mathrm{mg} / \mathrm{kg}$ (10 patients) or $3 \mathrm{mg} / \mathrm{kg}$ (10 patients), and the primary outcomes (best overall response assessed by RECIST) and secondary outcomes (drug safety, progression-free survival, overall survival, disease control rate and adverse events) were evaluated (Hamanishi et al. 2015). The most common treatment-related adverse events were increased serum hepatic enzymes, hypothyroidism, lymphocytopenia, decreased albumin, fever, rash, arthralgia, arrhythmia, fatigue and anemia. Grade 3 or 4 treatment-related adverse events occurred in eight patients, and treatment-related serious adverse events occurred in two patients. Among all patients, the 
Table 1 Results from clinical trials that have investigated immune checkpoint inhibitors in patients with ovarian carcinoma.

\begin{tabular}{|c|c|c|c|c|c|}
\hline Agent & Mechanism & Dose (mg/kg) & Patients & No. of patients & Phase \\
\hline BMS-936559 & Anti-PD-L1 & $0.3-10$ & $\begin{array}{l}\text { Advanced ovarian } \\
\text { cancer }\end{array}$ & 17 & I \\
\hline Ipilimumab & Anti-CTLA-4 & 3 & $\begin{array}{l}\text { Metastatic ovarian } \\
\text { cancer }\end{array}$ & 9 & I \\
\hline Ipilimumab & Anti-CTLA-4 & 10 & $\begin{array}{l}\text { Platinum-sensitive } \\
\text { ovarian cancer }\end{array}$ & 40 & II \\
\hline Nivolumab & Anti-PD-1 & 1 or 3 & $\begin{array}{l}\text { Platinum-resistant } \\
\text { ovarian cancer }\end{array}$ & 20 & II \\
\hline Pembrolizumab & Anti-PD-1 & 10 & $\begin{array}{l}\text { Advanced ovarian } \\
\text { cancer, failure to } \\
\text { prior treatment, } \\
\text { positive for PD-L1 }\end{array}$ & 26 & $\mathrm{Ib}$ \\
\hline Avelumab & Anti-PD-L1 & 10 & $\begin{array}{l}\text { Advanced ovarian } \\
\text { cancer }\end{array}$ & 124 & $\mathrm{Ib}$ \\
\hline Durvalumab + Olaparib & $\begin{array}{l}\text { Anti-PD-L1 + PPAR } \\
\text { inhibitor }\end{array}$ & $\begin{array}{l}10 \mathrm{mg} / \mathrm{kg} \\
\text { (durvalumab) + } 200 \text { or } \\
300 \mathrm{mg} \text { (olaparib) } 2 \times / \text { day; } \\
1500 \mathrm{mg} \\
\text { (durvalumab) }+300 \mathrm{mg} \\
\text { (olaparib) } 2 \times / \text { day }\end{array}$ & $\begin{array}{l}\text { Ovarian cancer and } \\
\text { triple-negative } \\
\text { breast cancer }\end{array}$ & $\begin{array}{l}10 \text { patients with ovarian } \\
\text { cancer }+2 \text { patients } \\
\text { with triple-negative } \\
\text { breast cancer }\end{array}$ & $\mathrm{I} / \mathrm{II}$ \\
\hline Durvalumab + Cediranib & $\begin{array}{l}\text { Anti-PD-L1 + VEGFR } \\
\text { inhibitor }\end{array}$ & $10 \mathrm{mg} / \mathrm{kg}+20$ or $30 \mathrm{mg}$ daily & $\begin{array}{l}\text { Ovarian cancer, } \\
\text { cervical cancer } \\
\text { and uterine } \\
\text { leiomyosarcoma }\end{array}$ & $\begin{array}{l}4 \text { patients with ovarian } \\
\text { cancer }+2 \text { patients } \\
\text { with cervical cancer }+1 \\
\text { patient with uterine } \\
\text { leiomyosarcoma }\end{array}$ & $\mathrm{I} / \mathrm{II}$ \\
\hline
\end{tabular}

best overall response rate was 15\%, and the disease control rate was $45 \%$. Interestingly, four patients had a durable and evident antitumor response, and two of them (both in the $3 \mathrm{mg} / \mathrm{kg}$ cohort) demonstrated complete response to treatment. For both cohorts, the median progressionfree survival time and median overall survival time were 3.5 and 20 months, respectively.

Pembrolizumab is also being investigated in ovarian cancer. In a phase Ib clinical trial, 26 patients with PD-L1-advanced solid tumors were enrolled to receive pembrolizumab at $10 \mathrm{mg} / \mathrm{kg}$, intravenously, every 2 weeks for up to 24 months (Varga et al. 2015).
The primary outcome measure was the best overall response using RECIST. The secondary outcome measures were progression-free survival, overall survival and duration of response in the participants who achieved partial response or better. The key eligibility criteria for the ovarian cancer cohort included advanced epithelial ovarian, fallopian tube or primary peritoneal carcinoma, failure of prior therapy and PD-L1 expression, and twenty-six patients were enrolled. Three patients responded (one patient with complete response and 2 patients with partial response), and 6 patients had stable disease. The best overall response rate was $11.5 \%$.

Published by Bioscientifica Ltd. 
Clinical activity

\begin{tabular}{|c|c|c|c|c|c|c|c|c|}
\hline & & & & & & & & \\
\hline PR & $\mathrm{CR}$ & ORR & SD & PD & $\begin{array}{l}\text { PFS } \\
\text { (median) }\end{array}$ & OS (median) & $\begin{array}{l}\text { Safety } \\
\text { ( } \% \text { of } \\
\text { grade } \\
3 / 4 \mathrm{AE} \text { ) }\end{array}$ & References \\
\hline $\begin{array}{l}6 \% \\
\text { (24 weeks) }\end{array}$ & $0 \%$ & $\begin{array}{l}6 \% \\
\text { (24 weeks) }\end{array}$ & $\begin{array}{l}18 \% \\
\text { (24 weeks) }\end{array}$ & NR & $N R^{a}$ & NR & $9 \mathrm{~b}$ & Brahmer et al. (2012) \\
\hline $\begin{array}{l}11.1 \% \\
\text { ( } \geq 4 \text { years) }\end{array}$ & NR & $11.10 \%$ & $\begin{array}{l}33.3 \% \text { (at least } \\
2 \text { months) }\end{array}$ & $66.70 \%$ & NR & NR & 22.20 & Hodi et al. (2008) \\
\hline NR & NR & $\begin{array}{l}\text { BORR of } \\
10.3 \% \text { by } \\
\text { RECIST, } \\
11.1 \% \text { by } \\
\text { CA- } 125 c\end{array}$ & NR & NR & NR & NR & 50 & NLM (2017) \\
\hline $\begin{array}{l}5 \% \text { (at least } \\
350 \text { days) }\end{array}$ & $\begin{array}{l}10 \% \text { (at least } \\
350 \text { days) }\end{array}$ & $\begin{array}{l}15 \% \text { (at least } \\
350 \text { days) }\end{array}$ & $\begin{array}{c}30 \% \text { (one pt } \\
\text { with almost } \\
400 \text { days) }\end{array}$ & $50 \%$ & 3.5 months & 20 months & 40 & $\begin{array}{l}\text { Hamanishi et al. } \\
(2015)\end{array}$ \\
\hline $\begin{array}{l}7.7 \% \\
(\geq 24 \text { weeks })\end{array}$ & $\begin{array}{l}3.8 \% \\
(\geq 24 \text { weeks })\end{array}$ & $\begin{array}{l}11.5 \% \\
(\geq 24 \text { weeks })\end{array}$ & $\begin{array}{l}23 \% \\
(\geq 24 \text { weeks })\end{array}$ & NR & NR & NR & 3.80 & Varga et al. (2015) \\
\hline $9.70 \%$ & $0 \%$ & $9.70 \%$ & $44.40 \%$ & NR & 11.3 weeks & 10.8 months & 6.50 & Disis et al. (2016) \\
\hline $\begin{array}{l}11.1 \% \\
\text { (6 months) }\end{array}$ & NR & NR & $\begin{array}{l}55.5 \% \\
\quad(\geq 4 \text { months })\end{array}$ & NR & NR & NR & $25 \%$ & Lee et al. (2016) \\
\hline $\begin{array}{l}28.5 \% \\
\text { (4 months) }\end{array}$ & NR & NR & $\begin{array}{l}28.5 \% \\
\text { (4 months) }\end{array}$ & NR & NR & NR & $N R^{d}$ & Lee et al. (2016) \\
\hline
\end{tabular}

aPFS of $22 \%$ at 24 weeks. bConsidering all patients in the study (both ovarian and non-ovarian cancer patients). cCA-125 level criteria of Rustin et al. (1996). dTotal number of patients with grade $3 / 4$ not provided.

$A E$, adverse events; $B O R R$, best overall response rate; $C R$, complete response; NR, not reported; ORR, objective response rate; OS, overall survival rate; $\mathrm{PD}$, progressive disease; PFS, progression-free survival rate; PR, partial response; SD, stable disease.

All patients experienced at least one adverse event, and the most common adverse events were fatigue, anemia and decreased appetite.

Anti-PD-L1 antibodies have been tested in patients with ovarian cancer. Brahmer and coworkers conducted a phase I clinical trial investigating the safety and clinical activity of intravenous anti-PD-L1 antibody in patients with advanced cancer (patients who had tumor progression after at least one previous course of tumorappropriate therapy for advanced or metastatic disease) (Brahmer et al. 2012). An escalating dose regimen was adopted, ranging from 0.3 to $10 \mathrm{mg} / \mathrm{kg}$ of body weight.
Anti-PD-L1 antibody was administered every 2 weeks in 6-week cycles for up to 16 cycles or until the patient had a complete response or confirmed disease progression. Seventeen women with ovarian cancer were enrolled. The objective response rate, stable disease for more than 24 weeks and progression-free survival rate at 24 weeks were 6, 18 and 22\%, respectively. In the cohort, almost all patients presented with adverse events of some grade. Fatigue, infusion reactions, diarrhea, arthralgia, rash, nausea, pruritus and headache were the most common adverse events; $9 \%$ of patients presented with treatmentrelated grade 3 or 4 events. 
The preliminary results of using avelumab in patients with ovarian cancer from the JAVELIN Solid Tumor phase Ib study were recently reported (Disis et al. 2016). One hundred and twenty-four patients with advanced ovarian cancer received avelumab at $10 \mathrm{mg} / \mathrm{kg}$, intravenously, every two weeks until progression, unacceptable toxicity or withdrawal, and they were followed for a median of 54 weeks. The objective response rate was 9.7\%, stable disease was observed in $44.4 \%$, and the disease control rate was $54 \%$. The majority of patients $(66.1 \%)$ experienced treatment-related adverse events; the most common adverse events were fatigue, infusion-related reaction and diarrhea. Severe grade 3/4 treatment-related adverse events were reported in 8 patients. Another phase I trial studying durvalumab, another PD-L1 inhibitor, in combination with olaparib (PARP inhibitor) or cediranib (VEGFR inhibitor) in patients with gynecological malignancies is currently ongoing, and the preliminary results are available (Lee et al. 2016). The authors enrolled a total of 19 patients with ovarian cancer, triple-negative breast cancer, cervical cancer or uterine leiomyosarcoma. Durvalumab plus olaparib yielded a disease control rate of $67 \%$, while durvalumab plus cediranib yielded a disease control rate of $57 \%$.

\section{Immune checkpoint inhibitors for treating thyroid cancer}

Thyroid cancer is the most common endocrine malignancy. The incidence of thyroid cancer has increased by more than $200 \%$ in the United States in the last four decades, and papillary thyroid carcinoma is the histological subtype responsible for the majority of these cases (Lim et al. 2017, Siegel et al. 2017). In addition to the increase in the incidence of papillary thyroid cancer with small tumors, the incidence rates have increased for tumors that are larger $(>5 \mathrm{~cm})$ and tumors with regional or distant dissemination (Enewold et al. 2009). A recent study demonstrated that the thyroid cancer incidencebased mortality has increased by $1.1 \%$ annually between 1994 and 2013 on average (Lim et al. 2017), prompting scientists to find new strategies to treat patients with this disease. Moreover, the not-insignificant number of patients with radioiodine-refractory thyroid cancers, the clinical success of tyrosine kinase inhibitors for this indication as well as for medullary thyroid cancer, the success of immunotherapy against other tumors with different histological origin and the availability of basket trials to test the same experimental drug for various different indications have recently fueled the field of tumor immunology in thyroid cancer.

The immune checkpoint has been investigated in the thyroid cancer microenvironment. We previously demonstrated that samples from thyroid cancer display more intense staining and higher mRNA levels of PD-L1 than those from benign tumors (Cunha et al. 2013a). In that study, we found a positive linear correlation between age at diagnosis and PD-L1 mRNA levels. Additionally, tumors at advanced stages displayed higher PD-L1 mRNA levels than tumors at early stages, suggesting that PD-L1/ PD-1 is likely associated with the aggressive phenotypes of thyroid cancer (Cunha et al. 2013a).

Ahn and coworkers observed that PD-L1 was more frequently expressed among anaplastic thyroid cancer, suggesting that PD-L1 expression was a late event in thyroid carcinogenesis (Ahn et al. 2017). However, the authors failed to demonstrate association between PD-L1 expression and clinicopathological variables of aggressiveness (Ahn et al. 2017). These results were confirmed by Zwaenepoel and coworkers, who found PD-L1 expression in $28.6 \%$ of anaplastic thyroid cancer (Zwaenepoel et al. 2017). PD-1 was not expressed on the tumor cells. Similarly, Bastman and coworkers identified PD-L1 expression in 13 out of 22 tumors and observed different immunohistochemical expression patterns in differentiated thyroid cancer (largely focal) and anaplastic thyroid cancer (more diffuse) (Bastman et al. 2016). Interestingly, they found that differentiated thyroid cancer was enriched with PD-1+CD4+ and CD8+ $T$ cells (Bastman et al. 2016). We also observed that PD-L1 expression was correlated with intratumoral infiltration of CD4+, CD8+, CD20+ and FOXP3+ cells; tumorassociated macrophages and myeloid-derived suppressor cells (Cunha et al. 2013a). Notably, differentiated thyroid tumors are frequently found to be enriched with a mixture of immune cells (e.g., mast cells, lymphocytes, macrophages) that may be complexly related to prognosis (French et al. 2017). By contrast, almost no expression of PD-L1 was found in medullary thyroid carcinoma cells and accompanying inflammatory cells. Certainly, more studies are warranted to replicate these results and clarify these findings (Bongiovanni et al. 2017).

Angell and coworkers demonstrated that papillary thyroid carcinomas harboring the BRAF V600E mutation frequently express PD-L1 (Angell et al. 2014). Similarly, positivity for the BRAF V600E mutation was associated with the expression of HLA-G (a nonclassical and inhibitory MHC class I molecule). Those authors found that tumors 
with BRAF V600E mutation presented lower CD8+/FOXP3+ cell ratios and were enriched with arginase-1+ myeloid populations (tumor-associated macrophages and myeloidderived suppressor cells). These results demonstrate that a strongly immunosuppressive molecular profile may be elicited in the tumor microenvironment of papillary thyroid carcinomas positive for the BRAF V600E mutation, suggesting that the promotion of tumor immune escape may be a mechanism by which the BRAF V600E mutation may contribute to aggressive tumor behavior (Angell et al. 2014). Following this rationale, Brauner and coworkers thoroughly investigated the PD-1/PD-L1 immune checkpoint mechanism in a thyroid cancer model (Brauner et al. 2016). In their study, the authors demonstrated that thyroid cell lines and tumor specimens with the BRAF V600E mutation displayed higher baseline expression of PD-L1 mRNA compared with BRAF WT thyroid cells and $B R A F W T$ tumor samples, respectively. They demonstrated that SCID mice injected with human thyroid cancer cells and treated with BRAF inhibitor for two weeks displayed significantly reduced in vivo expression of the PD-L1 mRNA. One week after tumor implantation, the mice were randomized for treatment with anti-PD-L1 antibody, PLX4720 (a selective inhibitor of oncogenic BRAF V600E (Tsai et al. 2008)) or a combination of the two agents. Treatment with anti-PD-L1 antibody alone was not able to reduce tumor volume. However, the authors showed that the combination of the BRAF V600E inhibitor and the anti-PD-L1 antibody acted synergistically, effectively reducing tumor volume compared to that in the other treatment groups. Notably, tumors from mice treated with anti-PD-L1 antibody or BRAF V600E inhibitor alone were markedly enriched with effector cytotoxic T cells, and the staining for granzyme B was increased in the combinatorial treatment group. These results suggest that immune checkpoint inhibitors that target PD-L1 along with BRAF V600E inhibitors would synergistically boost the cellular immune response of patients with thyroid cancer, promoting the effective elimination of tumor cells.

Severson and coworkers investigated the immune response triggered in metastasis in the lymph nodes of patients with differentiated thyroid cancer (Severson et al. 2015). They observed that PD-1+CD4+ cells and PD-1+CD8+ cells were enriched in 8/12 lymph node samples. The proliferative capacity of both $\mathrm{CD} 4+$ and CD8+ lymphocytes was maintained. Interestingly, the CD8+ cells from the PD-1+ lymphocyte-enriched lymph nodes were compromised in their ability to produce IL-2 and TNF $\alpha$ when compared with the control cells from lymph node samples that lacked resident PD-1+ T cells. Additionally, the authors observed that although the CD8+ T cells were capable of degranulation, their cytotoxic ability was impaired. These results suggest that the lymph node likely provides an inflammatory microenvironment that fails to completely eliminate tumors cells, but it maintains a residual potential of effective antitumor immune response that likely impedes tumor growth and dissemination. The authors further suggested that immunomodulatory therapies that inhibit PD-1/PD-L1, such as pembrolizumab and nivolumab, may be an option for patients with differentiated thyroid cancer and persistent lymph node metastasis.

Clinical trials evaluating immune checkpoint inhibitors against thyroid cancer are ongoing (Table 2). Preliminary results were obtained from the study NCT02054806 (Mehnert et al. 2016). Twenty-two patients with papillary or follicular advanced thyroid cancer, who failed standard therapy and presented with PD-L1 expression in $\geq 1 \%$ of tumor or stroma cells by immunohistochemistry, were treated with pembrolizumab at $10 \mathrm{mg} / \mathrm{kg}$ given every 2 weeks for up to 24 months or until confirmed progression, intolerable toxicity, death or withdrawal of consent. The median follow-up duration was 73.5 weeks. Eighteen patients had treatment-related adverse events; diarrhea and fatigue were the most common events, and none of the patients died or discontinued pembrolizumab because of adverse events. Two patients had a partial response, and the stable disease rate was $54.5 \%$. The 6 -month overall survival rate was $100 \%$, and the 6 -month progression-free survival rate was $58.7 \%$, suggesting that more studies are warranted in order to clarify the clinical benefit of pembrolizumab in patients with advanced thyroid cancer.

\section{Tracking immune checkpoint inhibitors in pancreatic cancer}

Pancreatic adenocarcinoma is an aggressive malignancy that displays a high rate of treatment resistance (Bazhin et al. 2014). At the time of diagnosis, the majority of patients are in advanced stages, and surgery has little or no impact on their prognosis (Ryan et al. 2014). The 5-year survival of patients with metastatic or recurrent tumors remains lower than 5\% in the most optimistic series, regardless of the diversity of treatment approaches, which has improved the therapeutic management (Conroy et al. 2011, Bazhin et al. 2014).
(C) 2017 Society for Endocrinology Printed in Great Britain
Published by Bioscientifica Ltd 

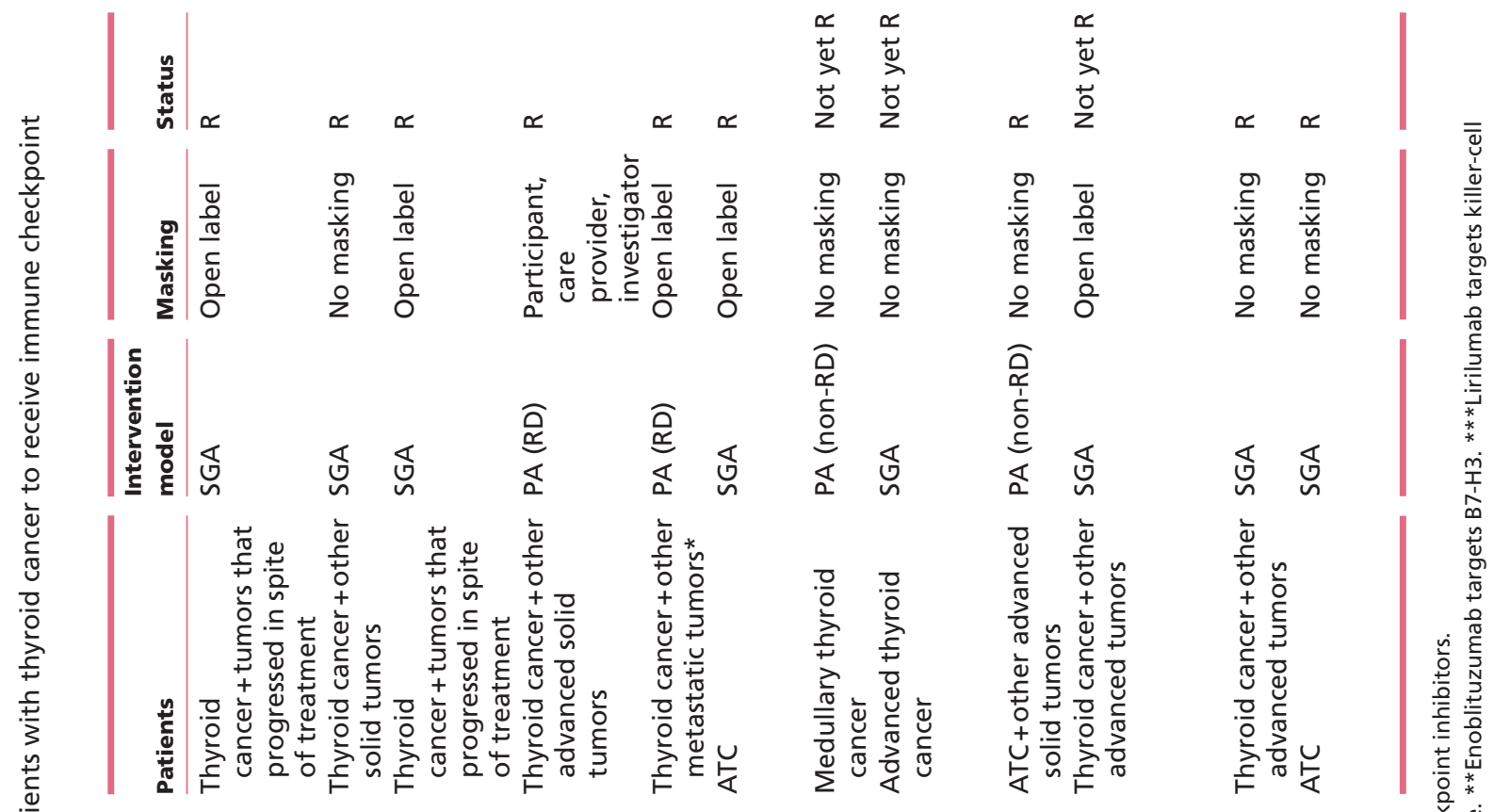

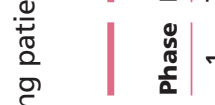
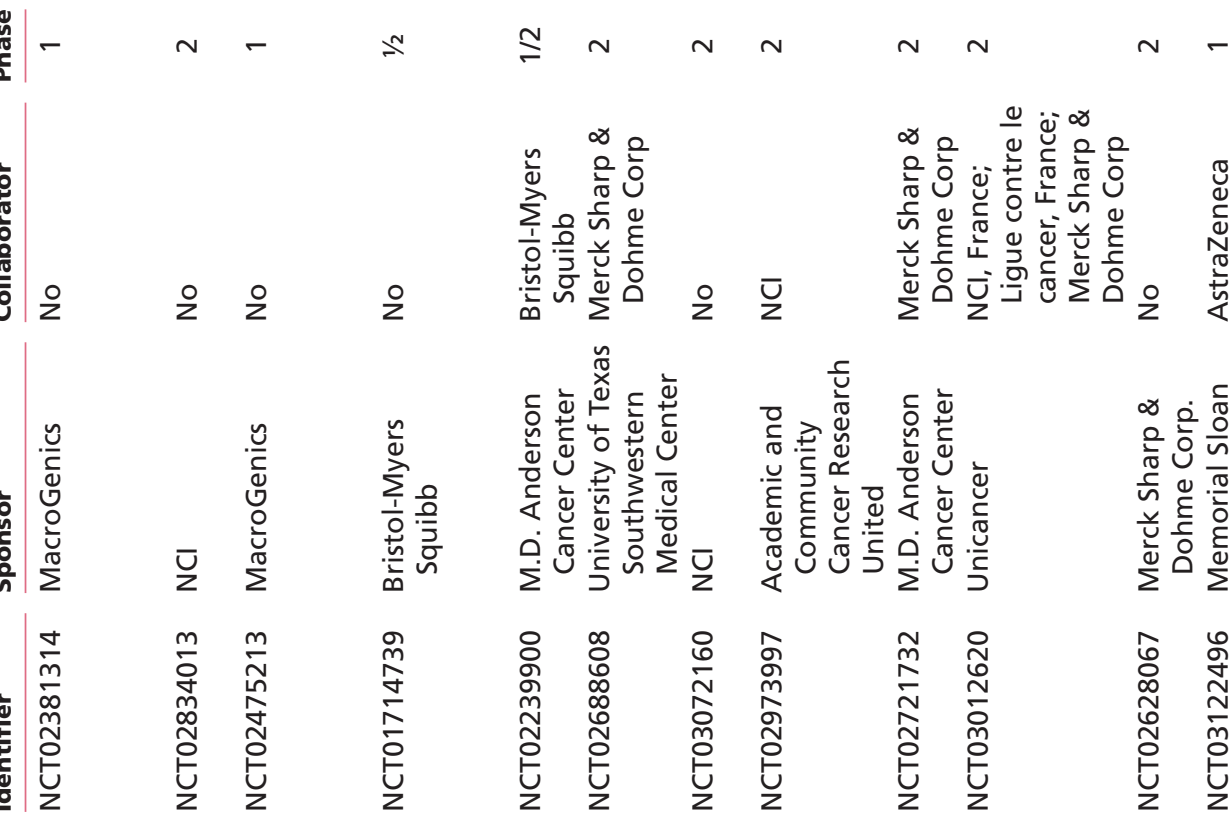

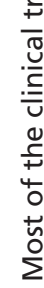

:

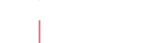

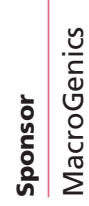
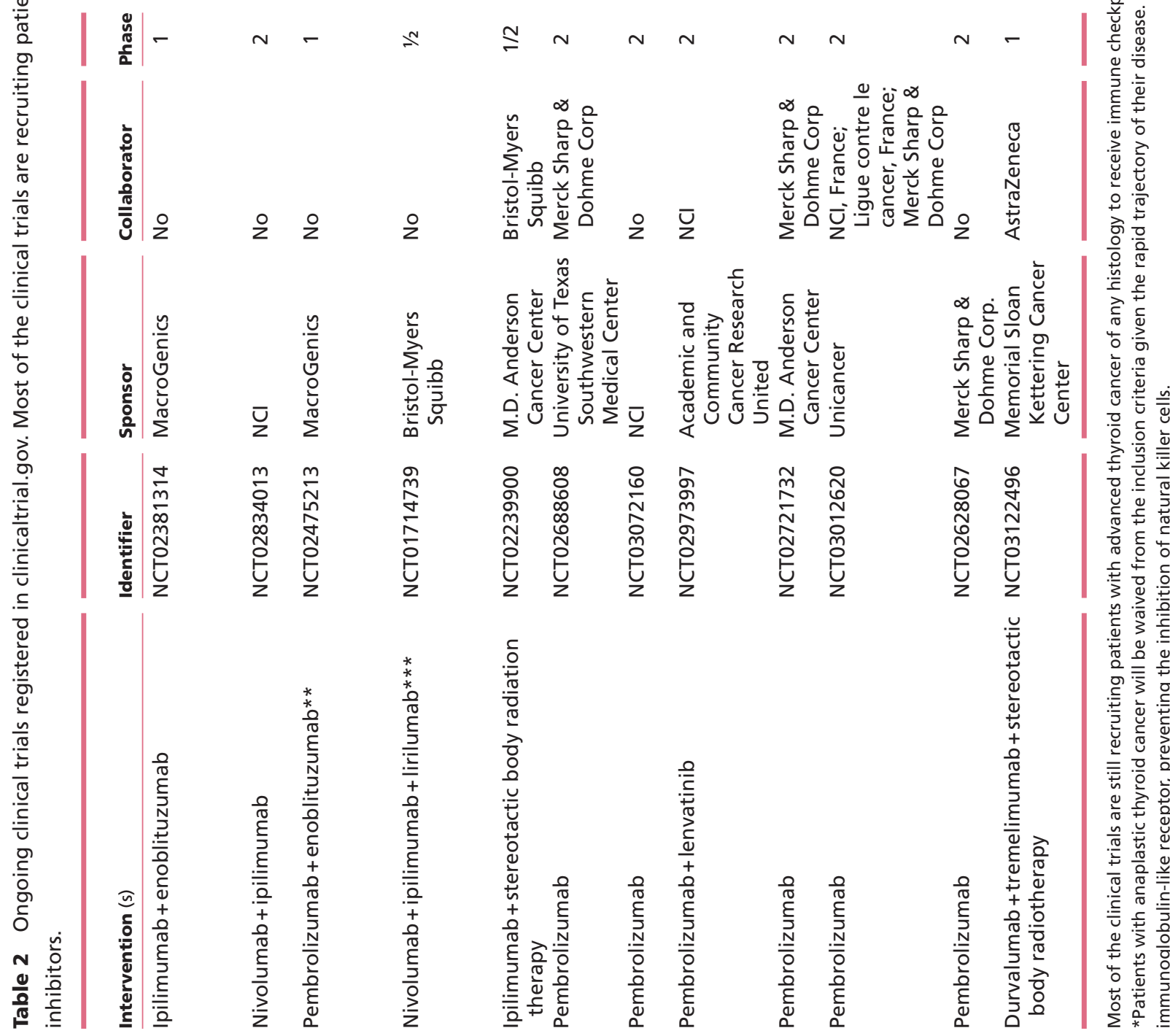

응

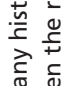

诺

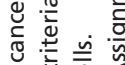

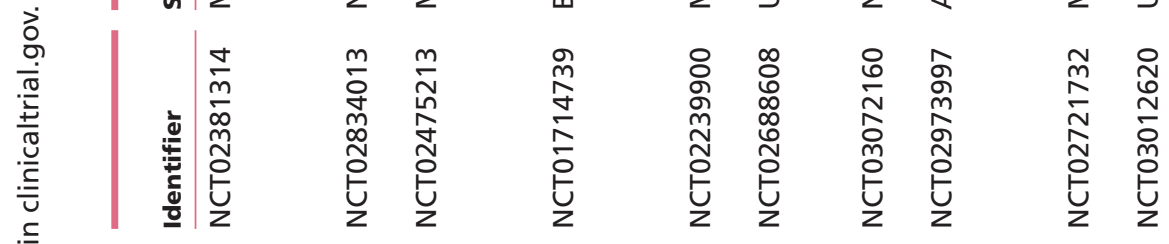


Immune checkpoint therapies appear to be promising mainly in combination with vaccines, radiation or cytotoxic agents. Some authors have demonstrated encouraging results, such as delayed progression of pancreatic adenocarcinoma with $3.0 \mathrm{mg} / \mathrm{kg}$ of ipilimumab (Royal et al. 2010). Similar results were found for the blockage of the PD-1/PD-L1 axis, and the anti-PD-L1 antibody exhibited disappointing results in a phase I trial in patients with pancreatic adenocarcinoma (Brahmer et al. 2012). Although many studies are currently ongoing, it is reasonable to say that single immune checkpoint blockage is not a clinical option at this time.

Why immune checkpoint therapy is not efficient in pancreatic adenocarcinoma is not completely understood. It has been speculated that PD-L1 expression is associated with responses to PD-1/PD-L1 blockage therapy. Since the majority of pancreatic adenocarcinoma cases are negative for PD-L1 (Nomi et al. 2007), this might help explain the lack of success of anti-PD-1/PD-L1 therapy. Additionally, poor survival was observed in patients whose tumors were positive for PD-L1, probably due to an immunosuppressive microenvironment mediated by PD-L1 expression (Nomi et al. 2007). Indeed, Clark and coworkers thoroughly investigated the immune response to pancreatic cancer in a mouse model and observed the lack of effector immune cells in the tumor microenvironment (Fig. 3) (Clark et al. 2007). The authors observed a marked infiltration of Treg cells into the pancreas even before the development of invasive disease (Clark et al. 2007). In addition, myeloidderived suppressive cells were observed at slightly elevated levels in pre-invasive lesions, but they became a prominent component of the leukocytic infiltrate in invasive pancreatic neoplasms (Fig. 3) (Clark et al. 2007). This markedly immunosuppressive microenvironment makes the use of immunotherapy in pancreatic adenocarcinoma particularly challenging.

An interesting strategy for overcoming the immunosuppressive tumor microenvironment may be the use of different combinations of immune checkpoint inhibitors and other treatments. The combined treatment with gemcitabine and PD-L1 blockade displayed a synergistic antitumor effect on pancreatic cancer, resulting in complete response in treated mice (Nomi et al. 2007). Furthermore, immune checkpoint inhibitors can be used with chemotherapeutic agents, since a synergistic effect was observed with ipilimumab and cytotoxic drugs in solid tumor models (Lynch et al. 2012, Jure-Kunkel et al. 2013). Le and coworkers performed a phase Ib, open-label, randomized study to investigate combinations of different modalities of immunotherapy (Le et al. 2013). They demonstrated that patients who received $10 \mathrm{mg} / \mathrm{kg}$ of ipilimumab combined with GVAX vaccine had a slightly longer survival than patients who received $10 \mathrm{mg} / \mathrm{kg}$ of ipilimumab alone. Radiotherapy could be an excellent adjuvant for immune checkpoint inhibitors. Interestingly, response in distant metastasis is observed when the primary tumor is irradiated (Blanquicett et al. 2005). The mechanism underlying this observation is unclear, but it is likely mediated by immunologic reactions (Vatner $e t a l$. 2014), thereby supporting the idea that the combination of immune checkpoint inhibitors and radiotherapy warrants further investigation.

\section{The initial assessment of immune checkpoints in other endocrine malignancies}

\section{Adrenocortical carcinoma}

Adrenocortical carcinoma is a rare endocrine malignancy, and the SEER database states that its estimated incidence is 0.72 cases per million per year in the United States (Kebebew et al. 2006). Adrenocortical carcinoma is an aggressive disease, and the stage of the tumor at diagnosis is the factor with the greatest impact on prognosis (Kerkhofs et al. 2015). Fay and coworkers investigated the expression of PD-L1 in adrenocortical carcinoma tissues (Fay et al. 2015).

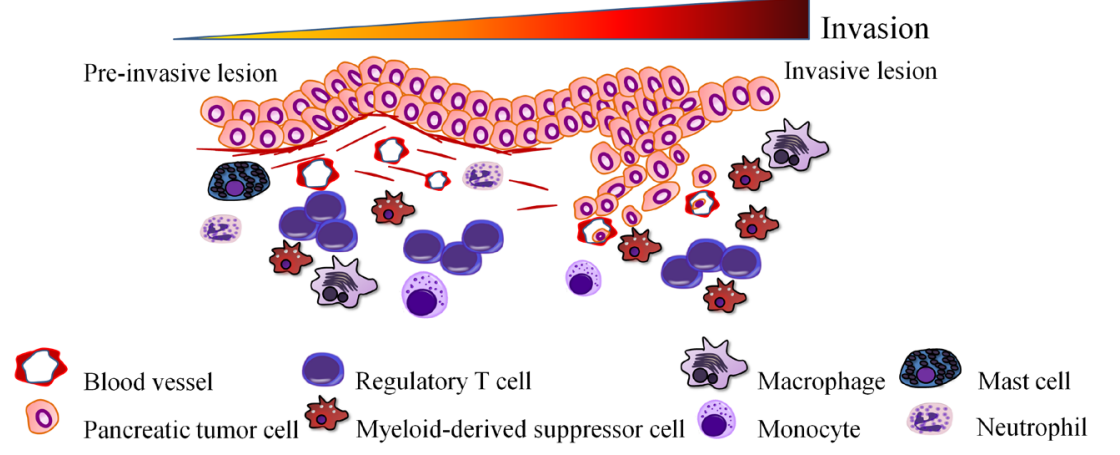

\section{Figure 3}

Immune microenvironment in pancreatic adenocarcinoma. Immune cells (e.g., T cells, macrophages, monocytes, mast cells, neutrophils and myeloid-derived suppressor cells) are frequently found in these tumors. Although some effector cells are sparsely observed in the leukocytic infiltrate, pancreatic cancer tissues are markedly infiltrated by immune cells with immunosuppressive functions, from early pre-invasive to advanced overt invasive stages. Additionally, invasive tumors are enriched in myeloid-derived suppressor cells. http://erc.endocrinology-journals.org DOI: 10.1530/ERC-17-0222
ㄷ 2017 Society for Endocrinology Printed in Great Britain
Published by Bioscientifica Ltd. 
They observed that PD-L1 was expressed in the membranes of tumor cells in 3/28 (10.7\%) patients. By contrast, PD-L1 was expressed by tumor-infiltrating lymphocytes in 19/27 (70.4\%) patients. PD-L1 in both tumor cells and tumorinfiltrating lymphocytes failed to predict prognosis in this set of patients. Although the severity of the disease demands new therapies, its rarity impairs the development of innovative approach in the field of immunotherapy. A small number of studies are registered in the clinical trials website.

\section{Neuroendocrine tumors}

Neuroendocrine tumors are typically slowly proliferating neoplasms. The standard treatment includes somatostatin analogues, IFN- $\alpha$, mTOR inhibitor and chemotherapy (Kotteas et al. 2016). Kim and coworkers investigated PD-L1 expression in 24 foregut-derived and 8 hindgutderived gastroenteropancreatic neuroendocrine tumors (Kim et al. 2016). They observed that only a minority (21.9\%) of samples expressed PD-L1 (Kim et al. 2016). Expression of PD-L1 was associated with high-grade classification and unfavorable prognosis (Kim et al. 2016). More studies are needed to elucidate the clinical role of blockage the PD-1/PD-L1 axis.

\section{Concluding remarks}

The promising results of immune checkpoint inhibitors have prompted academics, cancer survivors and investors to accelerate and improve research regarding the development of these drugs. This has resulted in five approved checkpoint inhibitors and several that are currently in clinical pipelines. Endocrine neoplasms are increasingly being addressed by using this therapeutic modality, and several ongoing studies are being conducted on patients with endocrine cancers. Notably, some tumor types (e.g., pancreatic adenocarcinoma, adrenocortical carcinoma and neuroendocrine tumors) require further study because the available data in the literature are not sufficient for clinical translation.

\section{Declaration of interest}

The authors declare that there is no conflict of interest that could be perceived as prejudicing the impartiality of this review.

\section{Funding}

This work was not supported by any specific grant from any funding agency in the public, commercial or not-for-profit sectors.

\section{Author contribution statement}

Lucas Leite Cunha: Conception and design, selection of notable articles for review, critical review of the literature, composition of the manuscript and final approval. Marjory Alana Marcello: Design, selection of notable articles for review, critical review of the literature, composition of the manuscript and final approval. Vinicius Rocha Santos: Design, selection of notable articles for review, critical review of the literature, composition of the manuscript, clinical and translational orientation and final approval. Laura Sterian Ward: Design, selection of notable articles for review, critical review of the literature, composition of the manuscript, clinical and translational orientation and final approval.

\section{Acknowledgements}

The authors acknowledge American Journal Experts for checking the English grammar.

\section{References}

Abiko K, Mandai M, Hamanishi J, Yoshioka Y, Matsumura N, Baba T, Yamaguchi K, Murakami R, Yamamoto A, Kharma B, et al. 2013 PD$\mathrm{L} 1$ on tumor cells is induced in ascites and promotes peritoneal dissemination of ovarian cancer through CTL dysfunction. Clinical Cancer Research 19 1363-1374. (doi:10.1158/1078-0432.CCR-12-2199)

Abiko K, Matsumura N, Hamanishi J, Horikawa N, Murakami R, Yamaguchi K, Yoshioka Y, Baba T, Konishi I \& Mandai M 2015 IFNgamma from lymphocytes induces PD-L1 expression and promotes progression of ovarian cancer. British Journal of Cancer 112 1501-1509. (doi:10.1038/bjc.2015.101)

Agrawal N, Jiao Y, Sausen M, Leary R, Bettegowda C, Roberts NJ, Bhan S, Ho AS, Khan Z, Bishop J, et al. 2013 Exomic sequencing of medullary thyroid cancer reveals dominant and mutually exclusive oncogenic mutations in RET and RAS. Journal of Clinical Endocrinology and Metabolism 98 E364-E369. (doi:10.1210/jc.2012-2703)

Ahamadi M, Freshwater T, Prohn M, Li CH, de Alwis DP, de Greef R, Elassaiss-Schaap J, Kondic A \& Stone JA 2017 Model-based characterization of the pharmacokinetics of pembrolizumab: a humanized anti-PD-1 monoclonal antibody in advanced solid tumors. CPT: Pharmacometrics and Systems Pharmacology 6 49-57. (doi:10.1002/psp4.12139)

Ahmadzadeh M, Johnson LA, Heemskerk B, Wunderlich JR, Dudley MF White DE \& Rosenberg SA 2009 Tumor antigen-specific CD8 T cells infiltrating the tumor express high levels of PD-1 and are functionally impaired. Blood 114 1537-1544. (doi:10.1182/blood2008-12-195792)

Ahn S, Kim TH, Kim SW, Ki CS, Jang HW, Kim JS, Kim JH, Choe JH, Shin JH, Hahn SY, et al. 2017 Comprehensive screening for PD-L1 expression in thyroid cancer. Endocrine-Related Cancer 24 97-106. (doi:10.1530/ERC-16-0421)

Angell TE, Lechner MG, Jang JK, Correa AJ, LoPresti JS \& Epstein AL 2014 BRAF V600E in papillary thyroid carcinoma is associated with increased programmed death ligand 1 expression and suppressive immune cell infiltration. Thyroid 24 1385-1393. (doi:10.1089/ thy.2014.0134)

Assal A, Kaner J, Pendurti G \& Zang X 2015 Emerging targets in cancer immunotherapy: beyond CTLA-4 and PD-1. Immunotherapy $\mathbf{7}$ 1169-1186. (doi:10.2217/imt.15.78)

AstraZeneca 2017 Highlights of the prescribing information: Imfinzi (durvalumab). Wilmington, DE, USA: AstraZeneca Pharmaceuticals LP. (available at: https://www.azpicentral.com/imfinzi/imfinzi.pdf)

Azuma T, Yao S, Zhu G, Flies AS, Flies SJ \& Chen L 2008 B7-H1 is a ubiquitous antiapoptotic receptor on cancer cells. Blood $\mathbf{1 1 1}$ 3635-3643. (doi:10.1182/blood-2007-11-123141) 
Bajaj G, Wang X, Agrawal S, Gupta M, Roy A \& Feng Y 2017 Modelbased population pharmacokinetic analysis of nivolumab in patients with solid tumors. CPT: Pharmacometrics and Systems Pharmacology 6 58-66. (doi:10.1002/psp4.12143)

Barber DL, Wherry EJ, Masopust D, Zhu B, Allison JP, Sharpe AH, Freeman GJ \& Ahmed R 2006 Restoring function in exhausted CD8 $\mathrm{T}$ cells during chronic viral infection. Nature 439 682-687. (doi:10.1038/nature04444)

Bastman JJ, Serracino HS, Zhu Y, Koenig MR, Mateescu V, Sams SB, Davies KD, Raeburn CD, McIntyre RC Jr, Haugen BR, et al. 2016 Tumor-infiltrating T cells and the PD-1 checkpoint pathway in advanced differentiated and anaplastic thyroid cancer. Journal of Clinical Endocrinology and Metabolism 101 2863-2873. (doi:10.1210/ jc.2015-4227)

Bates SE 2016 Endocrine cancers: defying the paradigms. Clinical Cancer Research 22 4980. (doi:10.1158/1078-0432.CCR-16-0366)

Bazhin AV, Shevchenko I, Umansky V, Werner J \& Karakhanova S 2014 Two immune faces of pancreatic adenocarcinoma: possible implication for immunotherapy. Cancer Immunology, Immunotherapy 63 59-65. (doi:10.1007/s00262-013-1485-8)

Beatty GL, O'Dwyer PJ, Clark J, Shi JG, Bowman KJ, Scherle PA, Newton RC, Schaub R, Maleski J, Leopold L, et al. 2017 First-inhuman phase i study of the oral inhibitor of indoleamine 2,3-dioxygenase-1 epacadostat (INCB024360) in patients with advanced solid malignancies. Clinical Cancer Research 23 3269-3276. (doi:10.1158/1078-0432.CCR-16-2272)

Berek JS, Crum C \& Friedlander M 2015 Cancer of the ovary, fallopian tube, and peritoneum. International Journal of Gynecology and Obstetrics 131 (Supplement 2) S111-S122. (doi:10.1016/j. ijgo.2015.06.007)

Blanquicett C, Saif MW, Buchsbaum DJ, Eloubeidi M, Vickers SM, Chhieng DC, Carpenter MD, Sellers JC, Russo S, Diasio RB, et al. 2005 Antitumor efficacy of capecitabine and celecoxib in irradiated and lead-shielded, contralateral human BxPC-3 pancreatic cancer xenografts: clinical implications of abscopal effects. Clinical Cancer Research 11 8773-8781. (doi:10.1158/10780432.CCR-05-0627)

Bongiovanni M, Rebecchini C, Saglietti C, Bulliard JL, Marino L, de Leval L \& Sykiotis GP 2017 Very low expression of PD-L1 in medullary thyroid carcinoma. Endocrine-Related Cancer 24 L35-L38. (doi:10.1530/ERC-17-0104)

Brahmer JR, Drake CG, Wollner I, Powderly JD, Picus J, Sharfman WH, Stankevich E, Pons A, Salay TM, McMiller TL, et al. 2010 Phase I study of single-agent anti-programmed death-1 (MDX-1106) in refractory solid tumors: safety, clinical activity, pharmacodynamics, and immunologic correlates. Journal of Clinical Oncology 28 3167-3175. (doi:10.1200/JCO.2009.26.7609)

Brahmer JR, Tykodi SS, Chow LQ, Hwu WJ, Topalian SL, Hwu P, Drake CG, Camacho LH, Kauh J, Odunsi K, et al. 2012 Safety and activity of anti-PD-L1 antibody in patients with advanced cancer. New England Journal of Medicine 366 2455-2465. (doi:10.1056/ NEJMoa1200694)

Brahmer JR, Hammers H \& Lipson EJ 2015 Nivolumab: targeting PD-1 to bolster antitumor immunity. Future Oncology 11 1307-1326. (doi:10.2217/fon.15.52)

Brauner E, Gunda V, Vanden Borre P, Zurakowski D, Kim YS, Dennett KV, Amin S, Freeman GJ \& Parangi S 2016 Combining BRAF inhibitor and anti PD-L1 antibody dramatically improves tumor regression and anti tumor immunity in an immunocompetent murine model of anaplastic thyroid cancer. Oncotarget 7 17194-17211. (doi:10.18632/oncotarget.7839)

Brignone C, Escudier B, Grygar C, Marcu M \& Triebel F 2009 A phase I pharmacokinetic and biological correlative study of IMP321, a novel MHC class II agonist, in patients with advanced renal cell carcinoma. Clinical Cancer Research 15 6225-6231. (doi:10.1158/1078-0432.CCR-09-0068)
Brignone C, Gutierrez M, Mefti F, Brain E, Jarcau R, Cvitkovic F, Bousetta N, Medioni J, Gligorov J, Grygar C, et al. 2010 First-line chemoimmunotherapy in metastatic breast carcinoma: combination of paclitaxel and IMP321 (LAG-3Ig) enhances immune responses and antitumor activity. Journal of Translational Medicine 871. (doi:10.1186/1479-5876-8-71)

Butte MJ, Keir ME, Phamduy TB, Sharpe AH \& Freeman GJ 2007 Programmed death-1 ligand 1 interacts specifically with the B7-1 costimulatory molecule to inhibit $\mathrm{T}$ cell responses. Immunity $\mathbf{2 7}$ 111-122. (doi:10.1016/j.immuni.2007.05.016)

Cai C, Xu YF, Wu ZJ, Dong Q, Li MY, Olson JC, Rabinowitz YM, Wang LH \& Sun Y 2016 Tim-3 expression represents dysfunctional tumor infiltrating T cells in renal cell carcinoma. World Journal of Urology 34 561-567. (doi:10.1007/s00345-015-1656-7)

Cheng G, Li M, Wu J, Ji M, Fang C, Shi H, Zhu D, Chen L, Zhao J, Shi L, et al. 2015 Expression of Tim-3 in gastric cancer tissue and its relationship with prognosis. International Journal of Clinical and Experimental Pathology 8 9452-9457.

Chin K, Chand VK \& Nuyten DS 2017 Avelumab: clinical trial innovation and collaboration to advance anti-PD-L1 immunotherapy. Annals of Oncology 28 1658-1666. (doi:10.1093/ annonc/mdx170)

Clark CE, Hingorani SR, Mick R, Combs C, Tuveson DA \& Vonderheide RH 2007 Dynamics of the immune reaction to pancreatic cancer from inception to invasion. Cancer Research 67 9518-9527. (doi:10.1158/0008-5472.CAN-07-0175)

Conroy T, Desseigne F, Ychou M, Bouche O, Guimbaud R, Becouarn Y, Adenis A, Raoul JL, Gourgou-Bourgade S, de la Fouchardiere C, et al. 2011 FOLFIRINOX versus gemcitabine for metastatic pancreatic cancer. New England Journal of Medicine 364 1817-1825. (doi:10.1056/NEJMoa1011923)

Cunha LL, Marcello MA, Morari EC, Nonogaki S, Conte FF, Gerhard R, Soares FA, Vassallo J \& Ward LS 2013a Differentiated thyroid carcinomas may elude the immune system by $\mathrm{B} 7 \mathrm{H} 1$ upregulation. Endocrine-Related Cancer 20 103-110. (doi:10.1530/ERC-12-0313)

Cunha LL, Marcello MA, Vassallo J \& Ward LS 2013b Differentiated thyroid carcinomas and their B7H1 shield. Future Oncology 9 1417-1419. (doi:10.2217/fon.13.89)

D'Incecco A, Andreozzi M, Ludovini V, Rossi E, Capodanno A, Landi L, Tibaldi C, Minuti G, Salvini J, Coppi E, et al. 2015 PD-1 and PD-L1 expression in molecularly selected non-small-cell lung cancer patients. British Journal of Cancer 112 95-102. (doi:10.1038/ bjc.2014.555)

Daud AI, Wolchok JD, Robert C, Hwu WJ, Weber JS, Ribas A, Hodi FS, Joshua AM, Kefford R, Hersey P, et al. 2016 Programmed deathligand 1 expression and response to the anti-programmed death 1 antibody pembrolizumab in melanoma. Journal of Clinical Oncology 34 4102-4109. (doi:10.1200/JCO.2016.67.2477)

de Coana YP, Wolodarski M, Poschke I, Yoshimoto Y, Yang Y, Nystrom M, Edback U, Brage SE, Lundqvist A, Masucci GV, et al. 2017 Ipilimumab treatment decreases monocytic MDSCs and increases CD8 effector memory T cells in long-term survivors with advanced melanoma. Oncotarget 8 21539-21553. (doi:10.18632/ oncotarget.15368)

Disis ML, Patel MR, Pant S, Hamilton EP, Lockhart AC, Kelly K, Beck JT Gordon MS, Weiss GJ, Taylor MH, et al. 2016 Avelumab (MSB0010718C; anti-PD-L1) in patients with recurrent/refractory ovarian cancer from the JAVELIN Solid Tumor phase Ib trial: safety and clinical activity. Journal of Clinical Oncology 34 (2_Suppl) 5533. (doi:10.1200/JCO.2016.34.15_suppl.5533)

Eggermont AM, Chiarion-Sileni V, Grob JJ, Dummer R, Wolchok JD, Schmidt H, Hamid O, Robert C, Ascierto PA, Richards JM, et al. 2015 Adjuvant ipilimumab versus placebo after complete resection of high-risk stage III melanoma (EORTC 18071): a randomised, doubleblind, phase 3 trial. Lancet Oncology 16 522-530. (doi:10.1016/S14702045(15)70122-1) 
Eggermont AM, Chiarion-Sileni V, Grob JJ, Dummer R, Wolchok JD, Schmidt H, Hamid O, Robert C, Ascierto PA, Richards JM, et al. 2016 Prolonged survival in stage III melanoma with ipilimumab adjuvant therapy. New England Journal of Medicine 375 1845-1855. (doi:10.1056/NEJMoa1611299)

Enewold L, Zhu K, Ron E, Marrogi AJ, Stojadinovic A, Peoples GE \& Devesa SS 2009 Rising thyroid cancer incidence in the United States by demographic and tumor characteristics, 1980-2005. Cancer Epidemiology, Biomarkers and Prevention 18 784-791. (doi:10.1158/1055-9965.EPI-08-0960)

Fay AP, Signoretti S, Callea M, Telomicron GH, McKay RR, Song J, Carvo I, Lampron ME, Kaymakcalan MD, Poli-de-Figueiredo CE, et al. 2015 Programmed death ligand-1 expression in adrenocortical carcinoma: an exploratory biomarker study. Journal for Immunotherapy of Cancer 3 3. (doi:10.1186/s40425-015-0047-3)

Fellner C 2012 Ipilimumab (yervoy) prolongs survival in advanced melanoma: serious side effects and a hefty price tag may limit its use. Pharmacy and Therapeutics 37 503-530.

Finke JH, Rini B, Ireland J, Rayman P, Richmond A, Golshayan A, Wood L, Elson P, Garcia J, Dreicer R, et al. 2008 Sunitinib reverses type-1 immune suppression and decreases T-regulatory cells in renal cell carcinoma patients. Clinical Cancer Research 14 6674-6682. (doi:10.1158/1078-0432.CCR-07-5212)

Frampton JE 2016 Lenvatinib: a review in refractory thyroid cancer. Target Oncology 11 115-122. (doi:10.1007/s11523-015-0416-3)

Francisco LM, Salinas VH, Brown KE, Vanguri VK, Freeman GJ, Kuchroo VK \& Sharpe AH 2009 PD-L1 regulates the development, maintenance, and function of induced regulatory T cells. Journal of Experimental Medicine 206 3015-3029. (doi:10.1084/jem.20090847)

French JD, Bible K, Spitzweg C, Haugen BR \& Ryder M 2017 Leveraging the immune system to treat advanced thyroid cancers. Lancet Diabetes and Endocrinology 5 469-481. (doi:10.1016/S22138587(16)30277-7)

Garon EB, Rizvi NA, Hui R, Leighl N, Balmanoukian AS, Eder JP, Patnaik A, Aggarwal C, Gubens M, Horn L, et al. 2015 Pembrolizumab for the treatment of non-small-cell lung cancer. New England Journal of Medicine 372 2018-2028. (doi:10.1056/ NEJMoa1501824)

Genentech 2017 Highlights of the prescribing information: Tecentriq (atezolizumab). San Francisco, CA, USA: Genentech Inc. (available at: https://www.gene.com/download/pdf/tecentriq_prescribing.pdf)

Ghiotto M, Gauthier L, Serriari N, Pastor S, Truneh A, Nunes JA \& Olive D 2010 PD-L1 and PD-L2 differ in their molecular mechanisms of interaction with PD-1. International Immunology 22 651-660. (doi:10.1093/intimm/dxq049)

Godin-Ethier J, Hanafi LA, Piccirillo CA \& Lapointe R 2011 Indoleamine 2,3-dioxygenase expression in human cancers: clinical and immunologic perspectives. Clinical Cancer Research 17 6985-6991. (doi:10.1158/1078-0432.CCR-11-1331)

Golden EB, Frances D, Pellicciotta I, Demaria S, Helen Barcellos-Hoff M \& Formenti SC 2014 Radiation fosters dose-dependent and chemotherapy-induced immunogenic cell death. Oncoimmunology 3 e28518. (doi:10.4161/onci.28518)

Gravelle P, Burroni B, Pericart S, Rossi C, Bezombes C, Tosolini M, Damotte D, Brousset P, Fournie JJ \& Laurent C 2017 Mechanisms of PD-1/PD-L1 expression and prognostic relevance in non-Hodgkin lymphoma: a summary of immunohistochemical studies. Oncotarget 8 44960-44975. (doi:10.18632/oncotarget.16680)

Grosso JF, Kelleher CC, Harris TJ, Maris CH, Hipkiss EL, De Marzo A, Anders R, Netto G, Getnet D, Bruno TC, et al. 2007 LAG-3 regulates CD8+ T cell accumulation and effector function in murine self- and tumor-tolerance systems. Journal of Clinical Investigation 117 3383-3392. (doi:10.1172/JCI31184)

Guo L, Zhang H \& Chen B 2017 Nivolumab as programmed death-1 (PD-1) inhibitor for targeted immunotherapy in tumor. Journal of Cancer 8 410-416. (doi:10.7150/jca.17144)
Hamanishi J, Mandai M, Abiko K, Matsumura N, Baba T, Yoshioka Y, Kosaka K \& Konishi I 2011 The comprehensive assessment of local immune status of ovarian cancer by the clustering of multiple immune factors. Clinical Immunology 141 338-347. (doi:10.1016/j. clim.2011.08.013)

Hamanishi J, Mandai M, Ikeda T, Minami M, Kawaguchi A, Murayama T, Kanai M, Mori Y, Matsumoto S, Chikuma S, et al. 2015 Safety and antitumor activity of anti-PD-1 antibody, nivolumab, in patients with platinum-resistant ovarian cancer. Journal of Clinical Oncology 33 4015-4022. (doi:10.1200/JCO.2015.62.3397)

Herbst RS, Soria JC, Kowanetz M, Fine GD, Hamid O, Gordon MS, Sosman JA, McDermott DF, Powderly JD, Gettinger SN, et al. 2014 Predictive correlates of response to the anti-PD-L1 antibody MPDL3280A in cancer patients. Nature 515 563-567. (doi:10.1038/ nature14011)

Higuchi T, Flies DB, Marjon NA, Mantia-Smaldone G, Ronner L, Gimotty PA \& Adams SF 2015 CTLA-4 blockade synergizes therapeutically with PARP inhibition in BRCA1-deficient ovarian cancer. Cancer Immunology Research 3 1257-1268. (doi:10.1158/23266066.CIR-15-0044)

Hodi FS, Mihm MC, Soiffer RJ, Haluska FG, Butler M, Seiden MV, Davis T, Henry-Spires R, MacRae S, Willman A, et al. 2003 Biologic activity of cytotoxic T lymphocyte-associated antigen 4 antibody blockade in previously vaccinated metastatic melanoma and ovarian carcinoma patients. PNAS 100 4712-4717. (doi:10.1073/ pnas.0830997100)

Hodi FS, Butler M, Oble DA, Seiden MV, Haluska FG, Kruse A, Macrae S, Nelson M, Canning C, Lowy I, et al. 2008 Immunologic and clinical effects of antibody blockade of cytotoxic T lymphocyte-associated antigen 4 in previously vaccinated cancer patients. PNAS $\mathbf{1 0 5}$ 3005-3010. (doi:10.1073/pnas.0712237105)

Hodi FS, O'Day SJ, McDermott DF, Weber RW, Sosman JA, Haanen JB, Gonzalez R, Robert C, Schadendorf D, Hassel JC, et al. 2010 Improved survival with ipilimumab in patients with metastatic melanoma. New England Journal of Medicine 363 711-723. (doi:10.1056/NEJMoa1003466)

Huang CT, Workman CJ, Flies D, Pan X, Marson AL, Zhou G, Hipkiss EL, Ravi S, Kowalski J, Levitsky HI, et al. 2004 Role of LAG-3 in regulatory T cells. Immunity 21 503-513. (doi:10.1016/j. immuni.2004.08.010)

Huang RR, Jalil J, Economou JS, Chmielowski B, Koya RC, Mok S, Sazegar H, Seja E, Villanueva A, Gomez-Navarro J, et al. 2011 CTLA4 blockade induces frequent tumor infiltration by activated lymphocytes regardless of clinical responses in humans. Clinical Cancer Research 17 4101-4109. (doi:10.1158/1078-0432.CCR-11-0407)

Japp AS, Kursunel MA, Meier S, Malzer JN, Li X, Rahman NA, Jekabsons W, Krause H, Magheli A, Klopf C, et al. 2015 Dysfunction of PSA-specific CD8+ T cells in prostate cancer patients correlates with CD38 and Tim-3 expression. Cancer Immunology, Immunotherapy 64 1487-1494. (doi:10.1007/s00262-015-1752-y)

Jayson GC, Kohn EC, Kitchener HC \& Ledermann JA 2014 Ovarian cancer. Lancet 384 1376-1388. (doi:10.1016/S0140-6736(13)62146-7)

Jiang GM, Wang HS, Du J, Ma WF, Wang H, Qiu Y, Zhang QG, Xu W, Liu HF \& Liang JP 2017 Bortezomib relieves immune tolerance in nasopharyngeal carcinoma via STAT1 suppression and indoleamine 2,3-dioxygenase downregulation. Cancer Immunology Research 5 42-51. (doi:10.1158/2326-6066.CIR-16-0102)

Ji P, Chen D, Bian J, Xia R, Song X, Wen W, Zhang X \& Zhu Y 2015 Up-regulation of TIM-3 on CD4+ tumor infiltrating lymphocytes predicts poor prognosis in human non-small-cell lung cancer. $X i B a O$ Yu Fen Zi Mian Yi Xue Za Zhi 31 808-811.

Jie HB, Gildener-Leapman N, Li J, Srivastava RM, Gibson SP, Whiteside TL \& Ferris RL 2013 Intratumoral regulatory T cells upregulate immunosuppressive molecules in head and neck cancer patients. British Journal of Cancer 109 2629-2635. (doi:10.1038/ bjc.2013.645)

Published by Bioscientifica Ltd. 
Jure-Kunkel M, Masters G, Girit E, Dito G, Lee F, Hunt JT \& Humphrey R 2013 Synergy between chemotherapeutic agents and CTLA-4 blockade in preclinical tumor models. Cancer Immunology, Immunotherapy 62 1533-1545. (doi:10.1007/s00262-013-1451-5)

Kebebew E, Reiff E, Duh QY, Clark OH \& McMillan A 2006 Extent of disease at presentation and outcome for adrenocortical carcinoma: have we made progress? World Journal of Surgery 30 872-878. (doi:10.1007/s00268-005-0329-x)

Keir ME, Liang SC, Guleria I, Latchman YE, Qipo A, Albacker LA, Koulmanda M, Freeman GJ, Sayegh MH \& Sharpe AH 2006 Tissue expression of PD-L1 mediates peripheral T cell tolerance. Journal of Experimental Medicine 203 883-895. (doi:10.1084/jem.20051776)

Keir ME, Butte MJ, Freeman GJ \& Sharpe AH 2008 PD-1 and its ligands in tolerance and immunity. Annual Review of Immunology 26 677-704. (doi:10.1146/annurev.immunol.26.021607.090331)

Kerkhofs TM, Ettaieb MH, Hermsen IG \& Haak HR 2015 Developing treatment for adrenocortical carcinoma. Endocrine-Related Cancer 22 R325-R338. (doi:10.1530/ERC-15-0318)

Kim ES 2017 Avelumab: first global approval. Drugs 77 929-937. (doi:10.1007/s40265-017-0749-6)

Kim ST, Ha SY, Lee S, Ahn S, Lee J, Park SH, Park JO, Lim HY, Kang WK, Kim KM, et al. 2016 The impact of PD-L1 expression in patients with metastatic GEP-NETs. Journal of Cancer 7 484-489. (doi:10.7150/ jca.13711)

Ko JS, Zea AH, Rini BI, Ireland JL, Elson P, Cohen P, Golshayan A, Rayman PA, Wood L, Garcia J, et al. 2009 Sunitinib mediates reversal of myeloid-derived suppressor cell accumulation in renal cell carcinoma patients. Clinical Cancer Research 15 2148-2157. (doi:10.1158/1078-0432.CCR-08-1332)

Kotteas E, Saif MW \& Syrigos K 2016 Immunotherapy for pancreatic cancer. Journal of Cancer Research and Clinical Oncology 142 1795-1805. (doi:10.1007/s00432-016-2119-2)

Kurman RJ 2013 Origin and molecular pathogenesis of ovarian highgrade serous carcinoma. Annals of Oncology 24 (Supplement 10) x16-x21. (doi:10.1093/annonc/mdt463)

Kuusk T, Albiges L, Escudier B, Grivas N, Haanen J, Powles T \& Bex A 2017 Antiangiogenic therapy combined with immune checkpoint blockade in renal cancer. Angiogenesis 20 205-215. (doi:10.1007/ s10456-017-9550-0)

Leach DR, Krummel MF \& Allison JP 1996 Enhancement of antitumor immunity by CTLA-4 blockade. Science 271 1734-1736. (doi:10.1126/science.271.5256.1734)

Le DT, Lutz E, Uram JN, Sugar EA, Onners B, Solt S, Zheng L, Diaz LA Jr, Donehower RC, Jaffee EM, et al. 2013 Evaluation of ipilimumab in combination with allogeneic pancreatic tumor cells transfected with a GM-CSF gene in previously treated pancreatic cancer. Journal of Immunotherapy 36 382-389. (doi:10.1097/cji.0b013e31829fb7a2)

Lee CS, Cragg M, Glennie M \& Johnson P 2013 Novel antibodies targeting immune regulatory checkpoints for cancer therapy. British Journal of Clinical Pharmacology 76 233-247. (doi:10.1111/bcp.12164)

Lee J-M, Zimmer ADS, Lipkowitz S, Annunziata CM, Ho TW, Chiou VL, Minasian LM, Houston ND, Ekwede I \& Kohn EC 2016 Phase I study of the PD-L1 inhibitor, durvalumab (MEDI4736; D) in combination with a PARP inhibitor, olaparib $(\mathrm{O})$ or a VEGFR inhibitor, cediranib (C) in women's cancers (NCT02484404). Journal of Clinical Oncology 34 3015-3015.

Lim H, Devesa SS, Sosa JA, Check D \& Kitahara CM 2017 Trends in thyroid cancer incidence and mortality in the United States, 1974-2013. JAMA 317 1338-1348. (doi:10.1001/jama.2017.2719)

Liu Y, Yu Y, Yang S, Zeng B, Zhang Z, Jiao G, Zhang Y, Cai L \& Yang R 2009 Regulation of arginase I activity and expression by both PD-1 and CTLA-4 on the myeloid-derived suppressor cells. Cancer Immunology, Immunotherapy 58 687-697. (doi:10.1007/s00262-0080591-5)

Lynch TJ, Bondarenko I, Luft A, Serwatowski P, Barlesi F, Chacko R, Sebastian M, Neal J, Lu H, Cuillerot JM, et al. 2012 Ipilimumab in combination with paclitaxel and carboplatin as first-line treatment in stage IIIB/IV non-small-cell lung cancer: results from a randomized, double-blind, multicenter phase II study. Journal of Clinical Oncology 30 2046-2054. (doi:10.1200/JCO.2011.38.4032)

Manning EA, Ullman JG, Leatherman JM, Asquith JM, Hansen TR, Armstrong TD, Hicklin DJ, Jaffee EM \& Emens LA 2007 A vascular endothelial growth factor receptor-2 inhibitor enhances antitumor immunity through an immune-based mechanism. Clinical Cancer Research 13 3951-3959. (doi:10.1158/1078-0432.CCR-07-0374)

Mehnert JM, Brose M, Aggarwal RR, Lin C-C, Prawira A, de Braud F, Tamura K, Doi T, Piha-Paul SA, Gilbert J, et al. 2016 Pembrolizumab for advanced papillary or follicular thyroid cancer: preliminary results from the phase 1b KEYNOTE-028 study. Journal of Clinical Oncology 34 6091. (doi:10.1200/JCO.2016.34.15_suppl.6091)

Melichar B, Nash MA, Lenzi R, Platsoucas CD \& Freedman RS 2000 Expression of costimulatory molecules CD80 and CD86 and their receptors CD28, CTLA-4 on malignant ascites CD3+ tumourinfiltrating lymphocytes (TIL) from patients with ovarian and other types of peritoneal carcinomatosis. Clinical and Experimental Immunology 119 19-27. (doi:10.1046/j.1365-2249.2000.01105.x)

Mellor A 2005 Indoleamine 2,3 dioxygenase and regulation of T cell immunity. Biochemical and Biophysical Research Communications 338 20-24. (doi:10.1016/j.bbrc.2005.08.232)

Meng X, Du G, Ye L, Sun S, Liu Q, Wang H, Wang W, Wu Z \& Tian J 2017 Combinatorial antitumor effects of indoleamine 2,3-dioxygenase inhibitor NLG919 and paclitaxel in a murine B16F10 melanoma model. International Journal of Immunopathology and Pharmacology 30 215-226. (doi:10.1177/0394632017714696)

Merck 2017 Highlights of the prescribing information: Keytruda (pembrolizumab). Whitehouse Station, NJ, USA: Merck \& Co. Inc. (available at: https://www.merck.com/product/usa/pi_circulars/k/ keytruda/keytruda_pi.pdf)

Neufeld G \& Kessler O 2006 Pro-angiogenic cytokines and their role in tumor angiogenesis. Cancer and Metastasis Reviews 25 373-385. (doi:10.1007/s10555-006-9011-5)

Ngiow SF, von Scheidt B, Akiba H, Yagita H, Teng MW \& Smyth MJ 2011 Anti-TIM3 antibody promotes T cell IFN-gamma-mediated antitumor immunity and suppresses established tumors. Cancer Research 71 3540-3551. (doi:10.1158/0008-5472.CAN-11-0096)

Ning YM, Suzman D, Maher VE, Zhang L, Tang S, Ricks T, Palmby T, Fu W, Liu Q, Goldberg KB, et al. 2017 FDA approval summary: atezolizumab for the treatment of patients with progressive advanced urothelial carcinoma after platinum-containing chemotherapy. Oncologist 22 743-749. (doi:10.1634/ theoncologist.2017-0087)

NLM 2017 NCT01611558: Phase II study of ipilimumab monotherapy in recurrent platinum-sensitive ovarian cancer. Bethesda, MD, USA: US National Library of Medicine. (available at: https:// clinicaltrials.gov/ct2/show/results/NCT01611558)

Nomi T, Sho M, Akahori T, Hamada K, Kubo A, Kanehiro H, Nakamura S, Enomoto K, Yagita H, Azuma M, et al. 2007 Clinical significance and therapeutic potential of the programmed death-1 ligand/programmed death-1 pathway in human pancreatic cancer. Clinical Cancer Research 13 2151-2157. (doi:10.1158/1078-0432.CCR-06-2746)

Ozao-Choy J, Ma G, Kao J, Wang GX, Meseck M, Sung M, Schwartz M, Divino CM, Pan PY \& Chen SH 2009 The novel role of tyrosine kinase inhibitor in the reversal of immune suppression and modulation of tumor microenvironment for immune-based cancer therapies. Cancer Research 69 2514-2522. (doi:10.1158/0008-5472.CAN-08-4709)

Pardoll DM 2012 The blockade of immune checkpoints in cancer immunotherapy. Nature Reviews Cancer 12 252-264. (doi:10.1038/ nrc3239)

Pico de Coana Y, Poschke I, Gentilcore G, Mao Y, Nystrom M, Hansson J, Masucci GV \& Kiessling R 2013 Ipilimumab treatment results in an early decrease in the frequency of circulating granulocytic myeloid-derived suppressor cells as well as their 
Arginase1 production. Cancer Immunology Research 1 158-162. (doi:10.1158/2326-6066.CIR-13-0016)

Pilones KA, Vanpouille-Box C \& Demaria S 2015 Combination of radiotherapy and immune checkpoint inhibitors. Seminars in Radiation Oncology 25 28-33. (doi:10.1016/j.semradonc.2014.07.004)

Raedler LA 2015 Keytruda (pembrolizumab): first PD-1 inhibitor approved for previously treated unresectable or metastatic melanoma. American Health and Drug Benefits 8 96-100.

Ramsay AG 2013 Immune checkpoint blockade immunotherapy to activate anti-tumour T-cell immunity. British Journal of Haematology 162 313-325. (doi:10.1111/bjh.12380)

Ribas A 2012 Tumor immunotherapy directed at PD-1. New England Journal of Medicine 366 2517-2519. (doi:10.1056/NEJMe1205943)

Ribas A, Puzanov I, Dummer R, Schadendorf D, Hamid O, Robert C, Hodi FS, Schachter J, Pavlick AC, Lewis KD, et al. 2015 Pembrolizumab versus investigator-choice chemotherapy for ipilimumab-refractory melanoma (KEYNOTE-002): a randomised, controlled, phase 2 trial. Lancet Oncology 16 908-918. (doi:10.1016/ S1470-2045(15)00083-2)

Robert C, Schachter J, Long GV, Arance A, Grob JJ, Mortier L, Daud A, Carlino MS, McNeil C, Lotem M, et al. 2015 Pembrolizumab versus ipilimumab in advanced melanoma. New England Journal of Medicine 372 2521-2532. (doi:10.1056/NEJMoa1503093)

Royal RE, Levy C, Turner K, Mathur A, Hughes M, Kammula US, Sherry RM, Topalian SL, Yang JC, Lowy I, et al. 2010 Phase 2 trial of single agent Ipilimumab (anti-CTLA-4) for locally advanced or metastatic pancreatic adenocarcinoma. Journal of Immunotherapy $\mathbf{3 3}$ 828-833. (doi:10.1097/CJI.0b013e3181eec14c)

Rustin GJ, Nelstrop AE, McClean P, Brady MF, McGuire WP, Hoskins WJ Mitchell H \& Lambert HE 1996 Defining response of ovarian carcinoma to initial chemotherapy according to serum CA 125. Journal of Clinical Oncology 14 1545-1551. (doi:10.1200/ JCO.1996.14.5.1545)

Ryan DP, Hong TS \& Bardeesy N 2014 Pancreatic adenocarcinoma. New England Journal of Medicine 371 1039-1049. (doi:10.1056/ NEJMra1404198)

Sakuishi K, Apetoh L, Sullivan JM, Blazar BR, Kuchroo VK \& Anderson AC 2010 Targeting Tim-3 and PD-1 pathways to reverse T cell exhaustion and restore anti-tumor immunity. Journal of Experimental Medicine 207 2187-2194. (doi:10.1084/jem.20100643)

Sakuishi K, Jayaraman P, Behar SM, Anderson AC \& Kuchroo VK 2011 Emerging Tim-3 functions in antimicrobial and tumor immunity. Trends in Immunology 32 345-349. (doi:10.1016/j.it.2011.05.003)

Serono 2017 Highlights of the prescribing information: Bavencio (avelumab). Rockland, MA, USA: EMD Serono Inc. (available at: https://medical.emdserono.com/content/dam/merck/health-care/ biopharma/web/USMI/Forms/Bavencio_PI_UC.pdf)

Severson JJ, Serracino HS, Mateescu V, Raeburn CD, McIntyre RC Jr, Sams SB, Haugen BR \& French JD 2015 PD-1+Tim-3+ CD8+ T lymphocytes display varied degrees of functional exhaustion in patients with regionally metastatic differentiated thyroid cancer. Cancer Immunology Research 3 620-630. (doi:10.1158/2326-6066. CIR-14-0201)

Shin T, Yoshimura K, Shin T, Crafton EB, Tsuchiya H, Housseau F, Koseki H, Schulick RD, Chen L \& Pardoll DM 2005 In vivo costimulatory role of B7-DC in tuning T helper cell 1 and cytotoxic $\mathrm{T}$ lymphocyte responses. Journal of Experimental Medicine $\mathbf{2 0 1}$ 1531-1541. (doi:10.1084/jem.20050072)

Siegel RL, Miller KD \& Jemal A 2017 Cancer statistics, 2017. CA: A Cancer Journal for Clinicians 67 7-30. (doi:10.3322/caac.21387)

Tartour E, Pere H, Maillere B, Terme M, Merillon N, Taieb J, Sandoval F, Quintin-Colonna F, Lacerda K, Karadimou A, et al. 2011 Angiogenesis and immunity: a bidirectional link potentially relevant for the monitoring of antiangiogenic therapy and the development of novel therapeutic combination with immunotherapy. Cancer and Metastasis Reviews 30 83-95. (doi:10.1007/s10555-011-9281-4)
Taube JM, Anders RA, Young GD, Xu H, Sharma R, McMiller TL, Chen S, Klein AP, Pardoll DM, Topalian SL, et al. 2012 Colocalization of inflammatory response with B7-h1 expression in human melanocytic lesions supports an adaptive resistance mechanism of immune escape. Science Translational Medicine 4 127ra137. (doi:10.1126/scitranslmed.3003689)

Taube JM, Klein A, Brahmer JR, Xu H, Pan X, Kim JH, Chen L, Pardoll DM, Topalian SL \& Anders RA 2014 Association of PD-1, PD-1 ligands, and other features of the tumor immune microenvironment with response to anti-PD-1 therapy. Clinical Cancer Research 205064 5074. (doi:10.1158/1078-0432.CCR-13-3271)

Taylor M, Dutcus CE, Schmidt E, Bagulho T, Li D, Shumaker R \& Rasco D 2016 A phase 1b trial of lenvatinib (LEN) plus pembrolizumab (PEM) in patients with selected solid tumors. Annals of Oncology 27 776PD-776PD.

Teng MW, Ngiow SF, Ribas A \& Smyth MJ 2015 Classifying cancers based on T-cell infiltration and PD-L1. Cancer Research $\mathbf{7 5}$ 2139-2145. (doi:10.1158/0008-5472.CAN-15-0255)

Tesniere A, Panaretakis T, Kepp O, Apetoh L, Ghiringhelli F, Zitvogel L \& Kroemer G 2008 Molecular characteristics of immunogenic cancer cell death. Cell Death and Differentiation 15 3-12. (doi:10.1038/ sj.cdd.4402269)

Theate I, van Baren N, Pilotte L, Moulin P, Larrieu P, Renauld JC, Herve C, Gutierrez-Roelens I, Marbaix E, Sempoux C, et al. 2015 Extensive profiling of the expression of the indoleamine 2,3-dioxygenase 1 protein in normal and tumoral human tissues. Cancer Immunology Research 3 161-172. (doi:10.1158/2326-6066. CIR-14-0137)

Thommen DS, Schreiner J, Muller P, Herzig P, Roller A, Belousov A, Umana P, Pisa P, Klein C, Bacac M, et al. 2015 Progression of lung cancer is associated with increased dysfunction of $\mathrm{T}$ cells defined by coexpression of multiple inhibitory receptors. Cancer Immunology Research 3 1344-1355. (doi:10.1158/2326-6066.CIR-15-0097)

Tivol EA, Borriello F, Schweitzer AN, Lynch WP, Bluestone JA \& Sharpe AH 1995 Loss of CTLA-4 leads to massive lymphoproliferation and fatal multiorgan tissue destruction, revealing a critical negative regulatory role of CTLA-4. Immunity $\mathbf{3}$ 541-547. (doi:10.1016/1074-7613(95)90125-6)

Tomek P, Palmer BD, Flanagan JU, Sun C, Raven EL \& Ching LM 2017 Discovery and evaluation of inhibitors to the immunosuppressive enzyme indoleamine 2,3-dioxygenase 1 (IDO1): Probing the active site-inhibitor interactions. European Journal of Medicinal Chemistry 126 983-996. (doi:10.1016/j.ejmech.2016.12.029)

Trinh VA \& Hagen B 2013 Ipilimumab for advanced melanoma: a pharmacologic perspective. Journal of Oncology Pharmacy Practice 19 195-201. (doi:10.1177/1078155212459100)

Tsai J, Lee JT, Wang W, Zhang J, Cho H, Mamo S, Bremer R, Gillette S, Kong J, Haass NK, et al. 2008 Discovery of a selective inhibitor of oncogenic B-Raf kinase with potent antimelanoma activity. PNAS 105 3041-3046. (doi:10.1073/pnas.0711741105)

Varga A, Piha-Paul SA, Ott PA, Mehnert JM, Berton-Rigaud D, Johnson EA, Cheng JD, Yuan S, Rubin EH \& Matei DE 2015 Antitumor activity and safety of pembrolizumab in patients (pts) with PD-L1 positive advanced ovarian cancer: Interim results from a phase Ib study. Journal of Clinical Oncology 33 5510. (doi:10.1200/ jco.2015.33.15_suppl.5510)

Vatner RE, Cooper BT, Vanpouille-Box C, Demaria S \& Formenti SC 2014 Combinations of immunotherapy and radiation in cancer therapy. Frontiers in Oncology 4 325. (doi:10.3389/fonc.2014.00325)

Velcheti V, Schalper KA, Carvajal DE, Anagnostou VK, Syrigos KN, Sznol M, Herbst RS, Gettinger SN, Chen L \& Rimm DL 2014 Programmed death ligand-1 expression in non-small cell lung cancer. Laboratory Investigation 94 107-116. (doi:10.1038/labinvest.2013.130)

Walker LS \& Sansom DM 2011 The emerging role of CTLA4 as a cellextrinsic regulator of T cell responses. Nature Reviews Immunology $\mathbf{1 1}$ 852-863. (doi:10.1038/nri3108) 
Wang C, Thudium KB, Han M, Wang XT, Huang H, Feingersh D, Garcia C, Wu Y, Kuhne M, Srinivasan M, et al. 2014 In vitro characterization of the anti-PD-1 antibody nivolumab, BMS-936558, and in vivo toxicology in non-human primates. Cancer Immunology Research 2 846-856. (doi:10.1158/2326-6066.CIR-14-0040)

Wang L, Amoozgar Z, Huang J, Saleh MH, Xing D, Orsulic S \& Goldberg MS 2015 Decitabine enhances lymphocyte migration and function and synergizes with CTLA- 4 blockade in a murine ovarian cancer model. Cancer Immunology Research 3 1030-1041. (doi:10.1158/2326-6066.CIR-15-0073)

Wang-Gillam A, Plambeck-Suess S, Goedegebuure P, Simon PO, Mitchem JB, Hornick JR, Sorscher S, Picus J, Suresh R, Lockhart AC, et al. 2013 A phase I study of IMP321 and gemcitabine as the frontline therapy in patients with advanced pancreatic adenocarcinoma. Investigational New Drugs 31 707-713. (doi:10.1007/s10637-012-9866-y)

Wingender G, Garbi N, Schumak B, Jungerkes F, Endl E, von Bubnoff D, Steitz J, Striegler J, Moldenhauer G, Tuting T, et al. 2006 Systemic application of CpG-rich DNA suppresses adaptive T cell immunity via induction of IDO. European Journal of Immunology 36 12-20. (doi:10.1002/eji.200535602)

Wolchok JD, Neyns B, Linette G, Negrier S, Lutzky J, Thomas L, Waterfield W, Schadendorf D, Smylie M, Guthrie T Jr, et al. 2010 Ipilimumab monotherapy in patients with pretreated advanced melanoma: a randomised, double-blind, multicentre, phase 2, doseranging study. Lancet Oncology 11 155-164. (doi:10.1016/S14702045(09)70334-1)
Woo SR, Turnis ME, Goldberg MV, Bankoti J, Selby M, Nirschl CJ, Bettini ML, Gravano DM, Vogel P, Liu CL, et al. 2012 Immune inhibitory molecules LAG-3 and PD-1 synergistically regulate T-cell function to promote tumoral immune escape. Cancer Research $\mathbf{7 2}$ 917-927. (doi:10.1158/0008-5472.CAN-11-1620)

Wu P, Wu D, Li L, Chai Y \& Huang J 2015 PD-L1 and survival in solid tumors: a meta-analysis. PLOS ONE 10 e0131403. (doi:10.1371/ journal.pone.0131403)

Xie J, Wang J, Cheng S, Zheng L, Ji F, Yang L, Zhang Y \& Ji H 2016 Expression of immune checkpoints in T cells of esophageal cancer patients. Oncotarget 7 63669-63678. (doi:10.18632/oncotarget.11611)

Yan J, Zhang Y, Zhang JP, Liang J, Li L \& Zheng L 2013 Tim-3 expression defines regulatory T cells in human tumors. PLOS ONE 8 e58006. (doi:10.1371/journal.pone.0058006)

Yang ZZ, Grote DM, Ziesmer SC, Niki T, Hirashima M, Novak AJ, Witzig TE \& Ansell SM 2012 IL-12 upregulates TIM-3 expression and induces $\mathrm{T}$ cell exhaustion in patients with follicular B cell nonHodgkin lymphoma. Journal of Clinical Investigation 122 1271-1282. (doi:10.1172/JCI59806)

Zhu C, Anderson AC \& Kuchroo VK 2011 TIM-3 and its regulatory role in immune responses. Current Topics in Microbiology and Immunology 350 1-15. (doi:10.1007/82_2010_84)

Zwaenepoel K, Jacobs J, De Meulenaere A, Silence K, Smits E, Siozopoulou V, Hauben E, Rolfo C, Rottey S \& Pauwels P 2017 CD70 and PD-L1 in anaplastic thyroid cancer - promising targets for immunotherapy. Histopathology 71 357-365. (doi:10.1111/his.13230)

Received in final form 3 August 2017

Accepted 10 September 2017

Accepted Preprint published online 11 September 2017
() 2017 Society for Endocrinology Printed in Great Britain
Published by Bioscientifica Ltd. 